\title{
Geochronology and petrology of pyroxene-garnet skarns (eastern Bohemian Massif): implications for the source and evolution of the Variscan continental crust
}

\author{
Jaroslava PERTOLDOVÁ1*, Monika KOŠULIČOVÁ1, Kryštof VERNER', Eliška ŽÁČKOVÁ', \\ Zdeněk PERTOLD ${ }^{2}$, Jiří KONOPÁSEK ${ }^{1,3}$, František VESELOVSKÝ', Jan KOŠLER ${ }^{1,3 \dagger}$ \\ ${ }^{1}$ Czech Geological Survey, Klárov 3, 11821 Prague 1, Czech Republic; jaroslava.pertoldova@geology.cz \\ ${ }^{2}$ Institute of Geochemistry, Mineralogy and Mineral Resources, Charles University, Albertov 6, 12843 Prague 2, Czech Republic \\ ${ }^{3}$ Centre for Geobiology and Department of Earth Science, University of Bergen, Allegaten 41, N-5007 Bergen, Norway \\ * Corresponding author \\ + Deceased
}

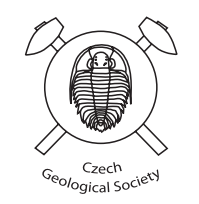

Zircon ages (U-Pb, LA-ICP-MS) obtained from skarns in the Kutná Hora and Svratka units and in the Moldanubian Zone (Bohemian Massif) show significant variations between the lithotectonic units as well as among samples from individual localities. The ages fall between $310 \mathrm{Ma}$ and $3.1 \mathrm{Ga}$. We suggest that such large spread is a result of both different zircon clastic grain sources and subsequent metamorphic histories. The oldest Neoarchaean to Neoproterozoic ages are interpreted as detrital zircon grains from pre-Cadomian basement. Pronounced age maxima between 600 and $520 \mathrm{Ma}$ (late Neoproterozoic to early Cambrian) were found in skarn samples from the Moldanubian Zone, Svratka and Kutná Hora units. We interpret these as maximum ages of skarn precursor deposition. Apparent Cambrian-OrdovicianSilurian to early Devonian zircon ages were obtained from non-mineralized samples of the Moldanubian Zone and also in the Kutná Hora Unit. This wide temporal interval could reflect maximum ages of skarn precursors related to disintegration of abundant early Palaeozoic magmatic rocks, provided the zircons were not modified by later metamorphism or fluid circulation. The early Carboniferous ages are interpreted to result from strong Variscan HT metamorphism and subsequent circulation of post-metamorphic fluids. Zircons of this age are dominant in skarns with massive magnetite mineralization, while the non-mineralized samples preserve the older ages.

Keywords: skarn, U-Pb zircon dating, Svratka Unit, Moldanubian Zone, Kutná Hora Unit, European Variscides Received: 17 March 2014; accepted: 5 November 2014; handling editor: G. Zulauf

The online version of this article (doi: 10.3190/jgeosci.181) contains supplementary electronic material.

\section{Introduction}

Petrogenesis of calc-silicate rocks dominated by garnet and pyroxene (skarns) is one of the most topical issues in geology of metamorphic complexes (e.g. Gaspar et al. 2008; Li et al. 2010; Xie et al. 2011; Shen et al. 2013; Chen et al. 2014). Reviews of skarn deposits on a global scale have been published by Einaudi et al. (1981), Burt (1982), Jamtveit et al. (1993), Nicolescu et al. (1998), Meinert (1998), Cepedal et al. (2000), Meinert et al. (2003), Baker et al. (2004), Levresse et al. (2004) and Meinert et al. (2005). The genesis of a majority of skarns worldwide was associated with contact metamorphism and metasomatic processes accompanied by igneousrelated hydrothermal input.

In the Bohemian Massif (Central European Variscides), skarns have been studied particularly with emphasis on the recognition of their pre-metamorphic history and the potential influence of metasomatic processes. Several petrogenetic interpretations of skarns have been invoked: (a) metasomatism (followed by metamorphism) (Koutek
1950; Němec 1991; Litochleb et al. 1997; Žáček 1997; Šrein and Šreinová 2000 and Žáček 2007), (b) regional metamorphism of sedimentary Fe-rich horizons (Zoubek 1946; Vrána 1987; Kotková 1991; Potužák 1996; Drahota et al. 2005), and (c) metamorphism of exhalative-sedimentary sources (e.g. Pertold et al. 1997; Pertoldová et al. 1998; Pertold et al. 2000 and Pertoldová et al. 2009).

Extensive occurrences of skarns in different settings across the Bohemian Massif provide an opportunity for petrogenetic research with broad implications. Currently, the Central European Variscides is one of the most important areas for the investigation of orogenic processes (e.g. Schulmann et al. 2005, 2009; Dörr and Zulauf 2010; Hajná et al. 2011; Žák et al. 2014). In particular, exceptional lithologies, such as skarns, are contributing to the reconstruction of the pre-Variscan and earlyVariscan evolution as high-grade metamorphic overprint obliterated the records of orogenic processes in many metasedimentary rocks.

Based on new U-Pb geochronological data on 12 skarn bodies in the eastern Bohemian Massif (Fig. 1), results of 


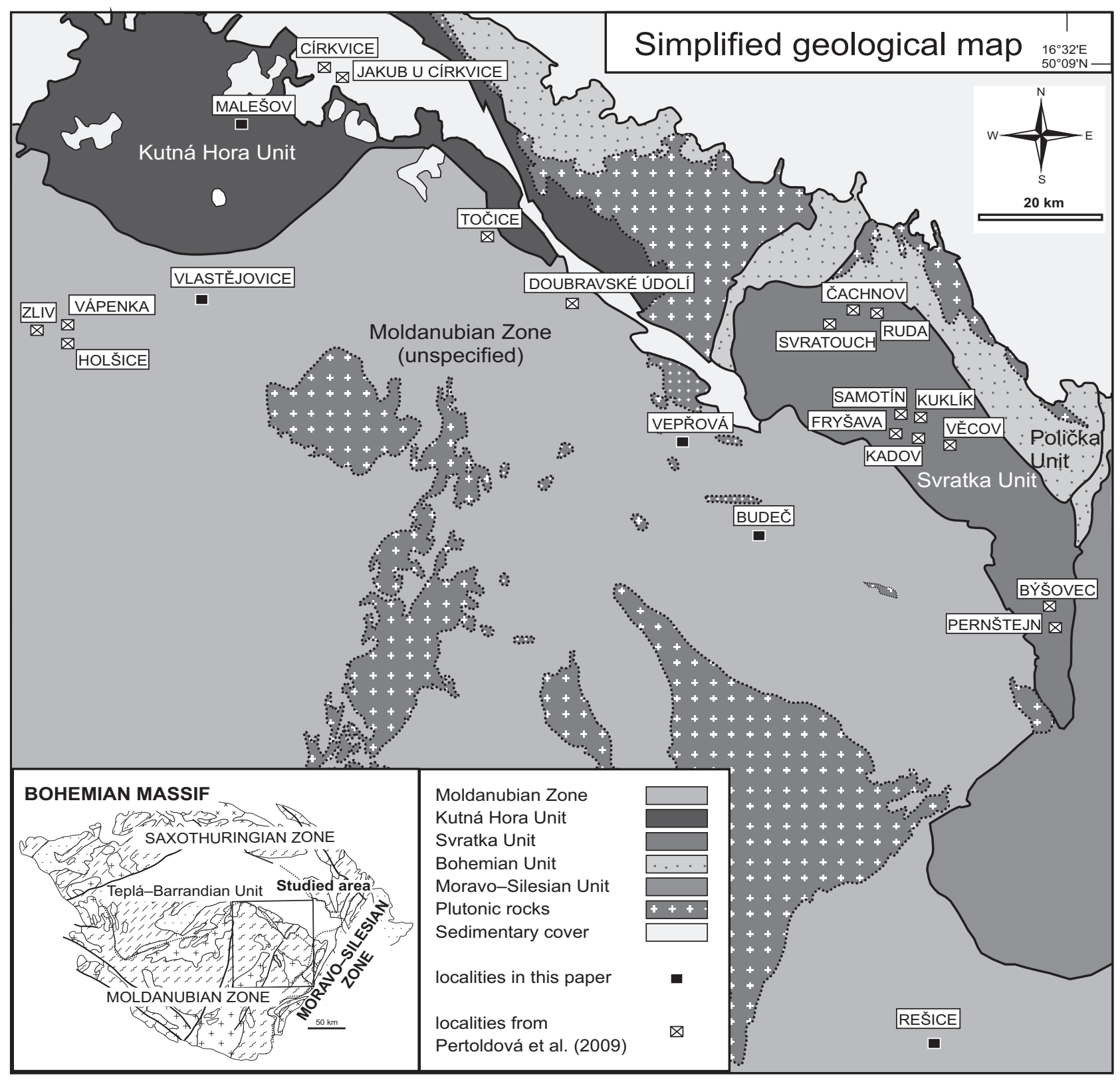

Fig. 1 Simplified geological map of the NE margin of the Moldanubian Zone, showing skarn localities. Modified after Cháb et al. (2007). Inset: sketch of the Bohemian Massif modified after Franke et al. (2000). Notes: black squares - sample localities, squares with crosses - skarn occurrences studied by Pertoldová et al. (2009).

petrological and structural investigations, and published geochemical data, we interpreted the pre-metamorphic precursors, origin and evolution of the skarns. These geochronological data also broaden our knowledge on the stratigraphy in the high-grade metamorphic units of the Bohemian Massif.

\section{Regional geological setting}

The investigated skarns are located in eastern Moldanubian Zone, Kutná Hora and Svratka units (Chlupáč and
Vrána 1994). These represent a deeper part of Variscan continental crust displaying the records of older, Neoproterozoic to early Palaeozoic geodynamic events (e.g. Urban and Synek 1995; Vrána et al. 1995; Verner et al. 2009; Schulmann et al. 2009; Pertoldová et al. 2010). Variscan processes ( $\sim 380$ to $310 \mathrm{Ma}$ ) were associated with collision of the Gondwana-derived microcontinents and the Old-Red Continent during Late Devonian to Carboniferous times and caused a high-grade tectonometamorphic overprint in the area of interest (e.g. Franke 2000; Schulmann et al. 2009). Early HP(MP)/HT metamorphism, WNW-ESE compression and crustal thickening 
were followed by a retrograde LP/HT metamorphism and polyphase regional deformation associated with oblique underthrusting of the Brunia promontory in the eastern part of the Bohemian Massif (e.g. Schulmann et al. 2009; Verner et al. 2009; Tajčmanová et al. 2010; Pertoldová et al. 2010).

The Svratka Unit is built by polymetamorphic migmatites, orthogneisses, paragneisses and micaschists with small bodies of marbles, amphibolites and skarns (e.g. Buriánek et al. 2009). During the Variscan orogeny, these rocks were affected by regional metamorphism and deformation at $\mathrm{T} \approx 580$ to $670^{\circ} \mathrm{C}$ and $\mathrm{P} \approx 0.5$ to $0.8 \mathrm{GPa}$ (Pitra and Guiraud 1996; Pertoldová et al. 2010). Relics of a pre-Variscan high-pressure event $(\sim 1.2 \mathrm{GPa})$ were identified in the skarns (Pertoldová et al. 2009). The structural pattern of the Svratka Unit is predominantly defined by transpressional metamorphic foliation dipping under moderate angles to the $\sim \mathrm{NNW}$ to NE associated with the $\sim \mathrm{NNW}$ plunging lineation (e.g. Verner et al. 2009).

The Moldanubian Zone comprises two major units with contrasting tectonometamorphic evolution, exhumed from different depths: the mid-crustal Drosendorf Unit and the lower-crustal Gföhl Unit (e.g. Urban and Synek 1995). The Drosendorf Unit consists of metasedimentary sequences dominated by sillimanite-biotite ( \pm cordierite) paragneisses, migmatized paragneisses, and migmatites (the so-called Monotonous Group) with abundant lensshaped bodies of quartzite, marble and amphibolite (altogether referred to as the Varied Group). The sedimentary precursor was Neoproterozoic to Late Ordovician in age (Košler et al. 2014). The P-T conditions of regional metamorphism were estimated in the range $\mathrm{T}=630$ to $720^{\circ} \mathrm{C}$ and $\mathrm{P}=0.3$ to $1 \mathrm{GPa}$ (e.g. Vrána et al. 1995 ; Racek et al. 2006). In contrast, the high-grade Gföhl Unit is composed of orthogneisses and migmatites with a substantial amount of lower crustal and mantle components such as high-pressure granulites, eclogites and peridotites. The $\mathrm{P}-\mathrm{T}$ conditions of regional metamorphism in the Gföhl Unit were significantly higher, estimated at 850 to $1000^{\circ} \mathrm{C}$ and 1.5 to $2.3 \mathrm{GPa}$ (e.g. Carswell and $\mathrm{O}^{\text {'B Brien }}$ 1993; O'Brien and Rötzler 2003; Racek et al. 2006, 2008). Conditions of the subsequent retrograde metamorphism were calculated at $\sim 600$ to $800^{\circ} \mathrm{C}$ and $\sim 0.6$ to $0.8 \mathrm{GPa}$ (e.g Racek 2006; Tajčmanová et al. 2006). The protolith age of high-grade orthogneisses from the Gföhl Unit was determined at $488 \pm 6 \mathrm{Ma}$ (Friedl et al. 2004). The structural pattern in the eastern Moldanubian Zone is complex and several regional fabrics were identified. In general, the steep NNE-SSW trending foliations were transposed to flat-lying orientation with well-developed NNE-SSW trending stretching lineation (e.g. Urban and Synek 1995; Schulmann et al. 2005, 2009; Verner et al. 2009; Pertoldová et al. 2010).
The Kutná Hora Unit consists of three sub-units with different rock assemblages and metamorphic evolution (e.g. Synek and Oliveriová 1993; Kachlík 1999; Faryad 2009; Štědrá and Nahodilová 2009; Verner et al. 2009; Perraki and Faryad 2014). Migmatites, granulites and upper-mantle ultramafic rocks containing relics of $\mathrm{HP}(\mathrm{UHP}) / \mathrm{HT}$ mineral assemblages crop out in the uppermost parts of the Kutná Hora Unit, referred to as the Malín and Plaňany sub-units (Vrána et al. 2005; Nahodilová et al. 2011). The underlying part corresponds to the Kouřim Nappe Sub-unit composed of mediumpressure orthogneisses or migmatites and rocks of the Mica Schist Sub-unit. The Kutná Hora Unit recorded an inverse, thrusting-related metamorphic pattern followed by retrogression under amphibolite-facies conditions (e.g. Synek and Oliveriová 1993; Verner et al. 2009; Vrána et al. 2009).

\subsection{Petrology and geological setting of skarns}

Table 1 shows a list of the analyzed skarn samples with their basic characteristics and locations. The skarn bodies have an elongated shape with prevailing dimensions of c. 0.1 to $0.6 \mathrm{~km} \times 0.5$ to $1.5 \mathrm{~km}$, oriented mostly parallel to the regional fabrics. They show well-developed compositional banding or have a massive nematoblastic or nemato-granoblastic texture. The fabric pattern of the studied skarns is described in Tab. 2. Based on petrological data, several types of skarn were distinguished in the Bohemian Massif (i.e. garnet-pyroxene skarns, garnet-amphibole skarns, pyroxene skarns with garnet, grunerite-pyroxene skarns with garnet, pyroxene-garnet skarns grading to garnetite \pm quartz and magnetite skarns). Petrological studies of skarns in the Moldanubian Zone, Svratka and Kutná Hora units were performed by Žáček (1997, 2007), Pertoldová et al. (1998, 2009), Pertold et al. (2000), Žáček et al. (2003), Drahota et al. (2005) and references therein.

\subsection{Whole-rock geochemistry of skarns}

Pertoldová et al. (2009) analyzed 69 whole-rock skarn samples from the Moldanubian, Svratka and Kutná Hora units for major and minor elements. The results were interpreted in terms of precursors as a mixture of sedimentary and exhalative components.

\section{Analytical methods}

Chemical analyses of minerals were carried out with a Cameca SX-100 electron-microprobe in the Joint Labo- 
Tab. 1 List of analyzed skarn samples from the Moldanubian Zone, Kutná Hora and Svratka units

\begin{tabular}{|c|c|c|c|c|c|c|c|c|}
\hline unit & locality & sample & skarn type & $\begin{array}{l}\text { zircon } \\
\text { dating }\end{array}$ & $\begin{array}{c}\text { WR } \\
\text { geochem. } \\
\text { analysis }\end{array}$ & $\begin{array}{l}\text { microprobe } \\
\text { analysis }\end{array}$ & WGS-84-N & WGS-84-E \\
\hline \multirow{2}{*}{ Svratka Unit (SU) } & \multirow{2}{*}{ Svratouch } & SV262 & Cpx-Grt-Gru & $\mathrm{xx}$ & & $\mathrm{xx}$ & $49^{\circ} 44.32^{\prime}$ & $16^{\circ} 01.66^{\prime}$ \\
\hline & & SV25 & Cpx-Grt & $\mathrm{xx}$ & $\mathrm{xx}$ & $\mathrm{xx}$ & $49^{\circ} 44.32^{\prime}$ & $16^{\circ} 01.66^{\prime}$ \\
\hline \multirow{10}{*}{$\begin{array}{l}\text { Moldanubian Zone } \\
\text { (MZ) }\end{array}$} & \multirow{2}{*}{ Budeč } & KM8/FV1 & Mag-Cpx -Grt & $\mathrm{x}$ & $\mathrm{xx}$ & $\mathrm{xx}$ & $49^{\circ} 32.25^{\prime}$ & $15^{\circ} 54.97^{\prime}$ \\
\hline & & KM8/FV3 & Grt-Cpx & $\mathrm{x}$ & $\mathrm{x}$ & $\mathrm{x}$ & $49^{\circ} 32.25^{\prime}$ & $15^{\circ} 54.97^{\prime}$ \\
\hline & Vepřová & $\mathrm{KM} 3 / \mathrm{FV}$ & Grt-Cpx & $\mathrm{x}$ & $\mathrm{xx}$ & $\mathrm{xx}$ & $49^{\circ} 37.86^{\prime}$ & $15^{\circ} 50.18^{\prime}$ \\
\hline & \multirow{3}{*}{ Vlastějovice } & KMVLA/FV1 & Cpx & $\mathrm{x}$ & $\mathrm{xx}$ & $\mathrm{x}$ & $49^{\circ} 44.26^{\prime}$ & $15^{\circ} 11.09^{\prime}$ \\
\hline & & KMVLA/FV2 & Grt-Cpx & $\mathrm{x}$ & $\mathrm{xx}$ & $\mathrm{x}$ & $49^{\circ} 44.26^{\prime}$ & $15^{\circ} 11.09^{\prime}$ \\
\hline & & KMVLA/FV3 & Grt-Mag & $\mathrm{x}$ & $\mathrm{x}$ & $\mathrm{x}$ & $49^{\circ} 44.26^{\prime}$ & $15^{\circ} 11.09^{\prime}$ \\
\hline & \multirow{4}{*}{$\begin{array}{l}\text { Rešice } \\
\text { (Gföhl Unit) }\end{array}$} & KMRES2 & $\mathrm{Cpx}-\mathrm{Hbl}-\mathrm{Grt}$ & $\mathrm{x}$ & $\mathrm{xx}$ & $\mathrm{xx}$ & $49^{\circ} 02.48^{\prime}$ & $16^{\circ} 09.02^{\prime}$ \\
\hline & & KMRES3 & Grt-Cpx & $\mathrm{x}$ & $\mathrm{xx}$ & $\mathrm{xx}$ & $49^{\circ} 02.48^{\prime}$ & $16^{\circ} 09.02^{\prime}$ \\
\hline & & KMRES5 & Cpx & $\mathrm{x}$ & $\mathrm{xx}$ & $\mathrm{x}$ & $49^{\circ} 02.48^{\prime}$ & $16^{\circ} 09.02^{\prime}$ \\
\hline & & KMRES6 & Cpx-Mag & $\mathrm{x}$ & $\mathrm{x}$ & $\mathrm{x}$ & $49^{\circ} 02.48^{\prime}$ & $16^{\circ} 09.02^{\prime}$ \\
\hline \multirow{2}{*}{$\begin{array}{l}\text { Kutná Hora Unit } \\
\text { (KHU) }\end{array}$} & \multirow{2}{*}{ Malešov } & KMMAL/FV1 & Grt-Mag & $\mathrm{x}$ & $x x$ & $\mathrm{xx}$ & $49^{\circ} 55.52^{\prime}$ & $15^{\circ} 13.56^{\prime}$ \\
\hline & & KMMAL/FV2 & Grt-Cpx & $\mathrm{x}$ & $\mathrm{xx}$ & $\mathrm{x}$ & $49^{\circ} 55.52^{\prime}$ & $15^{\circ} 13.56^{\prime}$ \\
\hline
\end{tabular}

Notes: $\mathrm{x}$ - in this study, $\mathrm{xx}$ - in Pertoldová et al. (2009), Gru = grunerite, WGS-84 = World Geodetic System 1984

ratory of Electron Microscopy and Microanalysis of the Masaryk University and the Czech Geological Survey in Brno. Operating conditions were $15 \mathrm{kV}$ accelerating voltage and $30 \mathrm{nA}$ beam current. The standards used were spessartine $(\mathrm{Si}, \mathrm{Mn})$, sanidine $(\mathrm{Al}, \mathrm{K})$, almandine $(\mathrm{Fe})$, hornblende (Ti), andradite $(\mathrm{Ca}), \mathrm{MgAl}_{2} \mathrm{O}_{4}(\mathrm{Mg})$, albite $(\mathrm{Na})$, fluorapatite $(\mathrm{P})$, chromite $(\mathrm{Cr})$ and other materials for REE and some minor elements. The beam was focused to $3 \mu \mathrm{m}$; the peak counting times were $20 \mathrm{~s}$. The raw data were reduced using PAP matrix corrections (Pouchou and Pichoir 1985). The analyses were recalculated to chemical formulae or end-member proportions using the MinPet software v. 2.02 of Richard (1995). The abbreviations of mineral names are after Kretz (1983).

The major-element analyses of the whole-rock samples were undertaken by wet chemistry in the laboratories of the Czech Geological Survey, Prague-Barrandov. The relative $2 \sigma$ uncertainties were smaller than $1 \%\left(\mathrm{SiO}_{2}\right)$, $2 \%(\mathrm{FeO}), 5 \%\left(\mathrm{Al}_{2} \mathrm{O}_{3}, \mathrm{~K}_{2} \mathrm{O}, \mathrm{Na}_{2} \mathrm{O}\right), 7 \%\left(\mathrm{TiO}_{2}, \mathrm{MnO}\right.$, $\mathrm{CaO}), 6 \%(\mathrm{MgO})$ and $10 \%\left(\mathrm{Fe}_{2} \mathrm{O}_{3}, \mathrm{P}_{2} \mathrm{O}_{5}\right)$ (Dempírová 2010). Trace elements including REE were analyzed by ICP-MS and AMA methods. For ICP-MS determinations, samples were decomposed by $\mathrm{HF}$ and $\mathrm{HClO}_{4}$, then were melted with lithium borate and sodium carbonate. After melting, they were taken out to solution with $\mathrm{HNO}_{3}$. Geochemical data were processed using the GCDkit software package (Janoušek et al. 2006a).

Zircon grains were extracted from the rock samples by conventional crushing and by heavy liquid and magnetic separation techniques. The grains were mounted in 1 inch epoxy-filled blocks and polished to obtain even surfaces suitable for laser-ablation ICP-MS analyses. Prior to analysis, the carbon coating was removed and the sample surfaces cleaned in deionised water and ethanol.
Isotopic analysis of zircons by laser-ablation ICP-MS followed the technique described in Košler et al. (2002) and Košler and Sylvester (2003). A Thermo-Finnigan Element 2 sector field ICP-MS coupled to a 213 NdYAG laser (New Wave UP-213) at Bergen University (Norway) was used to measure the $\mathrm{Pb} / \mathrm{U}$ and $\mathrm{Pb}$ isotopic ratios in the zircons. The raw data were corrected for the dead time of the electron multiplier, processed off line in the Lamdate spreadsheet-based program (Košler et al. 2002) and plotted on concordia diagrams using Isoplot (Ludwig 2003). Data reduction included correction for the gas blank, laser-induced elemental fractionation of $\mathrm{Pb}$ and $\mathrm{U}$ and instrument mass bias. No common $\mathrm{Pb}$ correction was applied to the data. Zircon reference materials 91500 (1065 Ma; Wiedenbeck et al. 1995) and Plešovice (338 Ma; Sláma et al. 2008) were periodically analysed during this study.

\section{Description of samples and results of $\mathrm{U}-\mathrm{Pb}$ zircon dating}

Petrological description and $\mathrm{U}-\mathrm{Pb}$ dating of zircon were performed for the following 12 skarn samples from the Moldanubian Zone (Drosendorf Unit): KM8/FV1, KM8/ FV3, KM3/FV, KMVLA/FV1, KMVLA/FV2, KMVLA/FV3; from the Moldanubian Zone (Gföhl Unit): KMRES2, KMRES3, KMRES5, KMRES6 and from the Kutná Hora Unit: KMMAL/FV1, KMMAL/FV2. A summary of petrological characteristics of the studied samples can be found in Tab. 3. Representative chemical analyses of garnet, clinopyroxene, amphibole and plagioclase are presented in Tabs 4-6. The isotopic ratios and corresponding ages, including the concordia ages 
(Ludwig 2003) for the studied samples are presented in Electronic Appendix (Tabs S1-S3). New major- and traceelement analyses of Budeč (KM8/FV3), Vlastějovice (KMVLA/FV3) and Rešice (KMRES6) samples are given in Tab. S4. The results conform to the previous major set of samples (Pertoldová et al. 2009).

\subsection{The Moldanubian Zone (Drosendorf Unit)}

The Vepřová and Budeč localities are situated in the northern and north-eastern parts of the Moldanubian Zone. Skarns form asymmetric bodies with longer axis of $\sim 500 \mathrm{~m}$ hosted by migmatites and migmatized paragneisses. Most rocks exhibit massive or banded structures. The geological situation is depicted in the Czech Geological Survey $1: 25,000$ maps (Hanžl et al. 2008; Hrdličková et al. 2008; Rejchrt et al. 2009).

Several lenticular skarns at the Vlastějovice locality occur together with a large body of two-mica orthogneiss in the NE-SW-trending synformal structure (Koutek 1950). The skarn and orthogneiss, together with minor bodies of amphibolite, marble, quartzite and rare eclogite, are hosted by migmatized paragneiss. The skarn bodies are highly heterogeneous, consisting of massive or banded garnetites \pm magnetite, garnet-pyroxene skarn, pyroxene skarn or garnet-pyroxene-epidote skarn. Three rock samples were collected from the largest skarn body (longer axis of up to several hundreds of metres) in an active quarry at the Holý vrch hill.

\subsubsection{Budeč, magnetite-garnet- clinopyroxene skarn KM8/FV1}

The main minerals are magnetite (up to $20-30$ vol. \%), garnet and clinopyroxene (Fig. 2a). Garnets are forming heterogeneous grains $\left(\mathrm{Grs}_{81-57} \mathrm{Alm}_{28-20}\right.$ $\mathrm{Sps}_{5-1} \mathrm{Adr}_{35-11}$ ). Fractures in older Grs-rich garnets are filled by younger andradite (Fig. 3a). The clinopyroxene compositions correspond to the diopside-hedenbergite series. Amphibole and epidote are

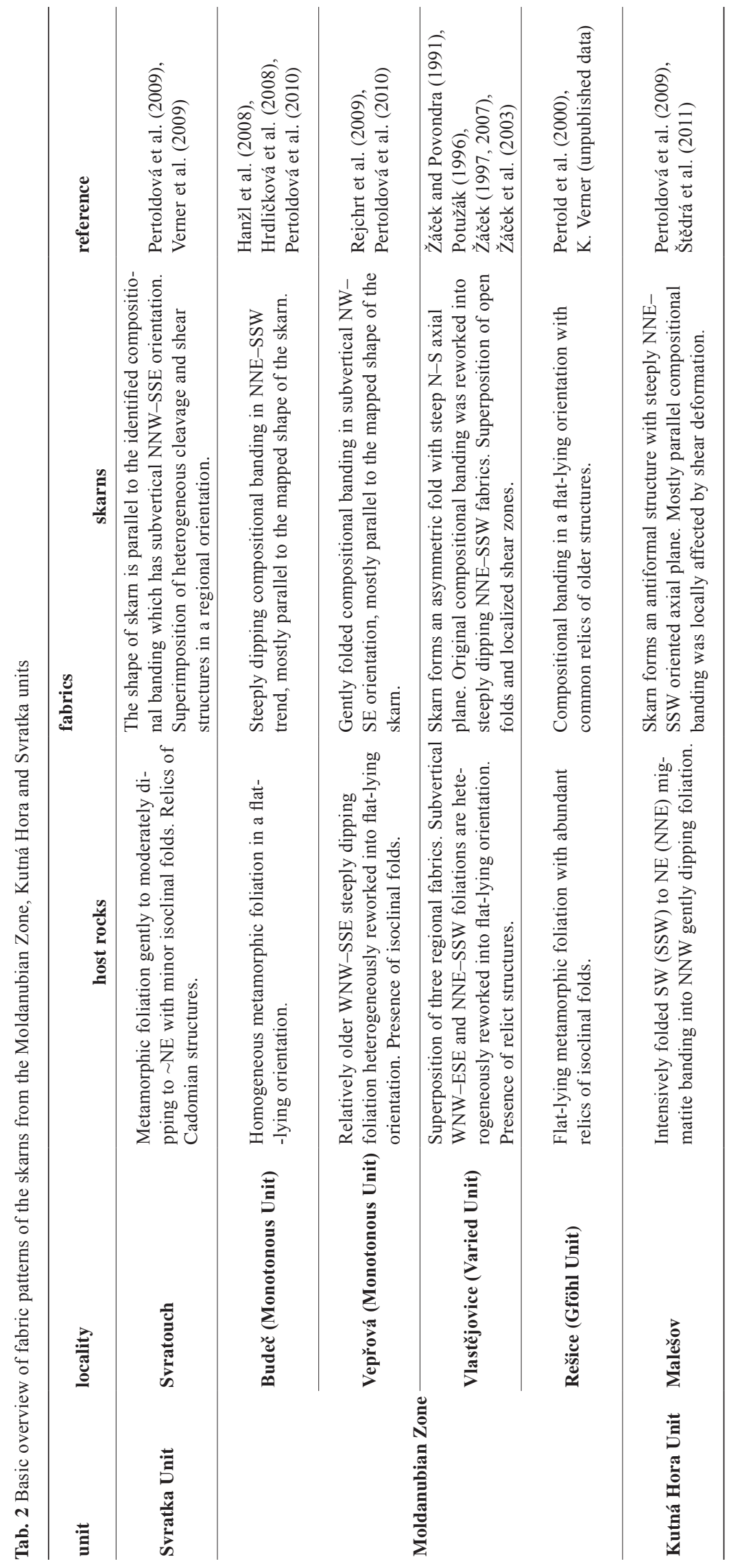




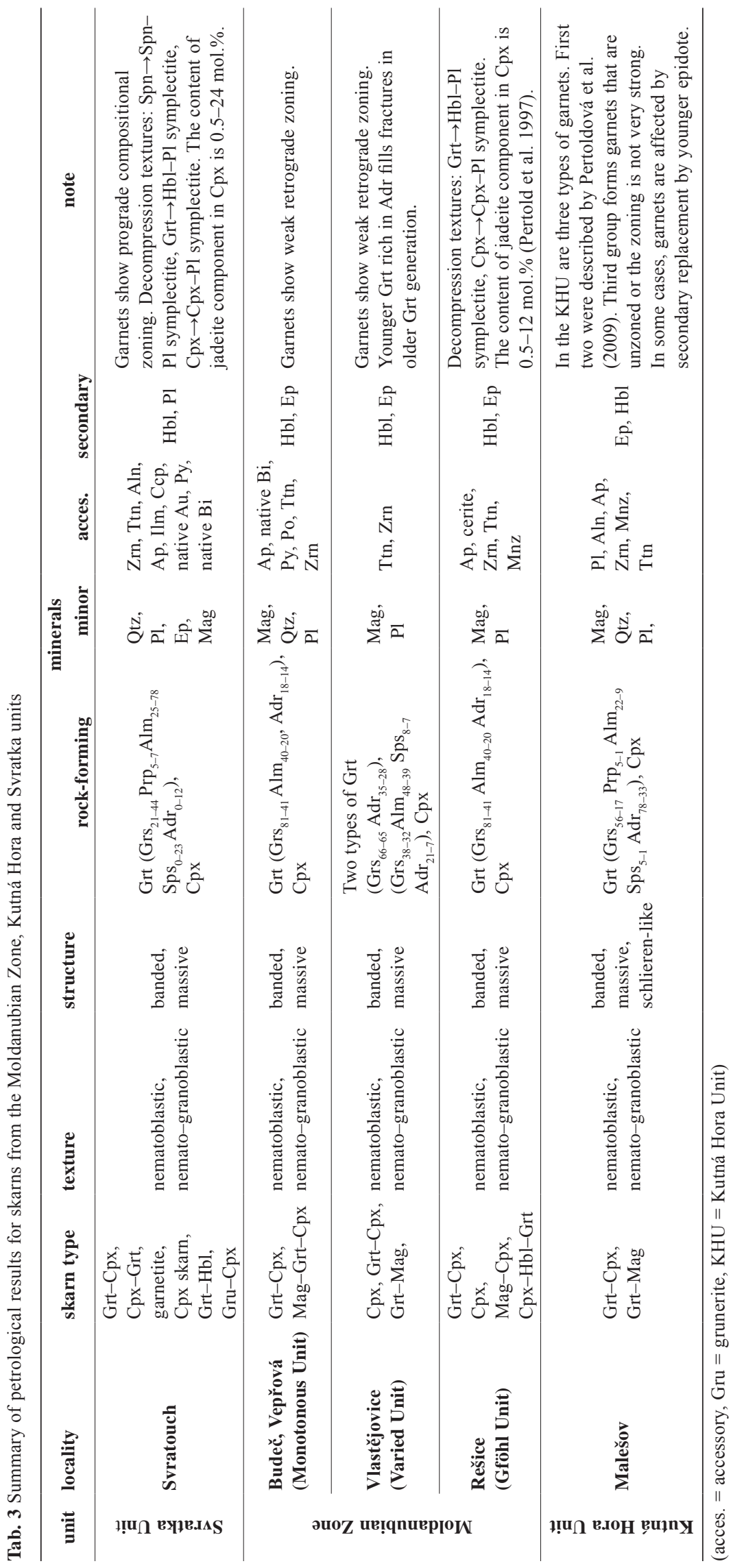

secondary minerals. Sample KM8/FV1 yielded very few zircon grains. They are rounded and very light brown in colour with a slightly pink hue. Cathodoluminescence images show irregular zoning (Fig. 5a).

Twenty five $\mathrm{U}-\mathrm{Pb}$ analyses of these zircon grains yielded equivalent and concordant results with a $345 \pm 2 \mathrm{Ma}$ age (Fig. 6a).

\subsubsection{Budeč, clinopyroxene- garnet skarn KM8/FV3}

Garnets form irregular bands (Fig. 2b) at the contacts with amphibole and pyroxene grains. Garnets show slight zoning ( $\left.\mathrm{Grs}_{51-49} \mathrm{Alm}_{40-36} \mathrm{Sps}_{7-3} \mathrm{Adr}_{7-3}\right)$. Clinopyroxenes are of the diopsidehedenbergite series. Zircon, titanite and apatite are accessories. Zircon grains are mostly light brown and their morphology ranges from rounded with crystal faces to elongated hypidiomorphic grains (Fig. 4a). Cathodoluminescence images show weak oscillatory zoning (Fig. 5b). The U-Pb dating of zircon (Fig. 6b-c) yielded a wide range of ages $(0.5-3.0 \mathrm{Ga})$. The corresponding age spectrum has a main peak at c. 520 Ma, a minor peak at c. $1.6-1.8 \mathrm{Ga}$ and individual data at c. $750 \mathrm{Ma}, 1.0 \mathrm{Ga}, 1.3$ Ga and 3.0 Ga.

\subsubsection{Vepřová, garnet-clinopyroxene skarn KM3/FV}

Garnet and clinopyroxene are major minerals (Fig. 2c). Plagioclase, quartz, epidote and amphibole are less abundant. Garnets are compositionally inhomogeneous and exhibit slight zoning $\left(\mathrm{Grs}_{88-77} \mathrm{Alm}_{0} \mathrm{Sps}_{4-2} \mathrm{Adr}_{21-9}\right)$. Clinopyroxene compositions correspond to the diopside-hedenbergite series. Zircon occurs as a common accessory mineral of light beige colour with rare crystal faces (Fig. 4b) and concentric oscillatory zoning (Fig. 5c). The concordia ages of 32 grains range between $c$. $500 \mathrm{Ma}$ and c. $1660 \mathrm{Ma}$ with a maximum at $550 \mathrm{Ma}$ (Fig. 6d-e). 
Geochronology of skarns from Bohemian Massif

Tab. 4 Representative chemical analyses of garnets from skarns of the Moldanubian Zone and the Kutná Hora Unit (wt. \% and apfu)

\begin{tabular}{|c|c|c|c|c|c|c|c|c|c|c|c|c|}
\hline \multirow{3}{*}{$\begin{array}{l}\text { location } \\
\text { sample } \\
\text { position }\end{array}$} & \multicolumn{6}{|c|}{ Moldanubian Zone } & \multirow{2}{*}{\multicolumn{2}{|c|}{$\begin{array}{c}\text { Gföhl Unit } \\
\text { KMRES6 }\end{array}$}} & \multicolumn{4}{|c|}{ Kutná Hora Unit } \\
\hline & \multicolumn{2}{|c|}{ KM8/FV3 } & \multicolumn{2}{|c|}{ KMVLA/FV2 } & \multicolumn{2}{|c|}{ KMVLA/FV3 } & & & \multicolumn{2}{|c|}{ KMMAL/FV1 } & \multicolumn{2}{|c|}{ KMMAL/FV2 } \\
\hline & core & rim & core & rim & core & rim & core & rim & core & rim & core & rim \\
\hline \multicolumn{13}{|l|}{ (wt. \%) } \\
\hline $\mathrm{SiO}_{2}$ & 37.88 & 37.66 & 37.53 & 36.32 & 35.81 & 37.65 & 38.10 & 37.91 & 36.54 & 36.49 & 36.35 & 36.39 \\
\hline $\mathrm{TiO}_{2}$ & 0.11 & 0.09 & 0.72 & 0.33 & 0.12 & 0.17 & 0.02 & 0.00 & 0.09 & 0.10 & 0.21 & 0.24 \\
\hline $\mathrm{Cr}_{2} \mathrm{O}_{3}$ & 0.04 & 0.03 & 0.03 & 0.00 & 0.00 & 0.01 & 0.00 & 0.01 & 0.01 & 0.00 & 0.01 & 0.00 \\
\hline $\mathrm{Al}_{2} \mathrm{O}_{3}$ & 19.73 & 19.39 & 14.99 & 10.25 & 6.31 & 12.58 & 19.32 & 19.67 & 8.24 & 8.06 & 9.65 & 9.50 \\
\hline $\mathrm{FeO}$ & 19.31 & 18.55 & 12.08 & 21.27 & 31.18 & 14.25 & 26.14 & 27.92 & 27.81 & 28.30 & 25.91 & 25.35 \\
\hline $\mathrm{MnO}$ & 1.99 & 2.95 & 0.39 & 0.52 & 0.47 & 0.42 & 0.62 & 0.82 & 0.36 & 0.35 & 0.48 & 0.57 \\
\hline $\mathrm{MgO}$ & 0.56 & 0.37 & 0.04 & 0.09 & 0.10 & 0.06 & 4.48 & 4.05 & 0.13 & 0.19 & 0.22 & 0.20 \\
\hline $\mathrm{CaO}$ & 19.17 & 19.84 & 33.59 & 30.95 & 24.37 & 33.65 & 10.71 & 9.52 & 26.19 & 25.74 & 26.12 & 26.98 \\
\hline $\mathrm{Na}_{2} \mathrm{O}$ & 0.01 & 0.02 & 0.01 & 0.01 & 0.02 & 0.00 & 0.02 & 0.00 & 0.00 & 0.01 & 0.01 & 0.01 \\
\hline $\mathrm{F}$ & 0.12 & 0.23 & 0.08 & 0.12 & 0.12 & 0.15 & 0.08 & 0.03 & 0.00 & 0.00 & 0.12 & 0.19 \\
\hline Total & 98.92 & 99.12 & 99.46 & 99.86 & 98.50 & 98.93 & 99.48 & 99.94 & 99.37 & 99.25 & 99.08 & 99.41 \\
\hline \multicolumn{13}{|c|}{$(\mathrm{apfu})^{*}$ Number of ions on the basis of $12 \mathrm{O}$} \\
\hline $\mathrm{Si}$ & 3.00 & 3.00 & 2.99 & 3.00 & 3.00 & 3.00 & 3.00 & 3.00 & 3.00 & 3.01 & 3.00 & 3.00 \\
\hline $\mathrm{Ti}$ & 0.01 & 0.01 & 0.04 & 0.02 & 0.01 & 0.01 & 0.00 & 0.00 & 0.00 & 0.00 & 0.01 & 0.00 \\
\hline $\mathrm{Cr}$ & 0.00 & 0.00 & 0.00 & 0.00 & 0.00 & 0.00 & 0.00 & 0.00 & 0.00 & 0.00 & 0.00 & 0.00 \\
\hline $\mathrm{Al}$ & 1.85 & 1.82 & 0.00 & 0.00 & 0.63 & 1.18 & 1.80 & 1.83 & 0.46 & 0.83 & 0.94 & 0.46 \\
\hline $\mathrm{Fe}^{2+}$ & 1.19 & 1.08 & 0.00 & 0.00 & 0.11 & 0.79 & 1.54 & 1.66 & 0.04 & 0.06 & 0.65 & 0.58 \\
\hline $\mathrm{Fe}^{3+}$ & 0.09 & 0.14 & 0.60 & 1.04 & 1.28 & 0.76 & 0.17 & 0.17 & 1.54 & 1.15 & 1.03 & 1.05 \\
\hline Mn & 0.13 & 0.20 & 0.03 & 0.04 & 0.03 & 0.03 & 0.04 & 0.05 & 0.13 & 0.05 & 0.03 & 0.13 \\
\hline $\mathrm{Mg}$ & 0.05 & 0.04 & 0.00 & 0.01 & 0.01 & 0.01 & 0.52 & 0.48 & 0.00 & 0.00 & 0.03 & 0.00 \\
\hline $\mathrm{Ca}$ & 1.64 & 1.69 & 2.87 & 2.74 & 2.21 & 2.88 & 0.91 & 0.81 & 2.82 & 2.90 & 2.31 & 2.82 \\
\hline $\mathrm{Na}$ & 0.00 & 0.00 & 0.00 & 0.00 & 0.00 & 0.00 & 0.00 & 0.00 & 0.00 & 0.00 & 0.00 & 0.00 \\
\hline $\mathrm{F}$ & 0.00 & 0.00 & 0.00 & 0.00 & 0.00 & 0.00 & 0.00 & 0.00 & 0.00 & 0.13 & 0.00 & 0.00 \\
\hline \multicolumn{13}{|l|}{$(\mathrm{mol} . \%)$} \\
\hline Alm & 39.54 & 35.75 & 4.49 & 7.93 & 25.79 & 3.71 & 51.11 & 55.39 & 1.24 & 2.06 & 21.43 & 19.10 \\
\hline Adr & 4.27 & 7.03 & 29.71 & 51.73 & 63.05 & 37.44 & 8.60 & 8.34 & 76.96 & 57.41 & 51.00 & 52.20 \\
\hline Grs & 50.03 & 49.10 & 64.72 & 38.73 & 9.56 & 57.69 & 21.57 & 18.56 & 17.18 & 38.90 & 25.49 & 26.55 \\
\hline Prp & 1.64 & 1.44 & 0.14 & 0.38 & 0.41 & 0.22 & 17.25 & 15.90 & 4.54 & 1.59 & 0.90 & 0.80 \\
\hline Sps & 4.46 & 6.60 & 0.87 & 1.19 & 1.11 & 0.94 & 1.39 & 1.82 & 4.49 & 1.56 & 1.11 & 1.31 \\
\hline
\end{tabular}

* recaltulated after Green and Ringwood (1968), $\mathrm{Fe}^{2+} / \mathrm{Fe}^{3+}$ was estimated according to Droop (1987)

\subsubsection{Vlastějovice, clinopyroxene skarn KMVLA/FV1}

The sample is massive with nematoblastic structure (Fig. 2d). Clinopyroxene generally belongs to the hedenbergite-diopside group. Replacement of clinopyroxene by secondary amphibole is common. Titanite, garnet and apatite are accessory minerals. Garnet has slight chemical zoning in the Alm, Grs and Adr components $\left(\mathrm{Grs}_{38-32}\right.$ $\left.\mathrm{Alm}_{48-39} \mathrm{Sps}_{8-7} \mathrm{Adr}_{21-7}\right)$. The morphology of the zircon grains ranges from rounded to partly rounded grains with preserved crystal faces. Zircons are light orange in colour and CL images show oscillatory zoning (Fig. 5d). The resulting data for 39 grains are presented in Fig. 7a-b. The age spectrum contains one main peak at c. $600 \mathrm{Ma}$, one minor peak at c. 1.8 Ga and individual data at c. $500 \mathrm{Ma}, 750 \mathrm{Ma}$ and $2.2 \mathrm{Ga}$.

\subsubsection{Vlastějovice, garnet-clinopyroxene skarn KMVLA/FV2}

The main minerals, garnet and clinopyroxene, are accompanied by less abundant plagioclase and amphibole, as well as accessory minerals zircon, titanite and apatite (Fig. 2e). Garnet is present in two generations with contrasting optical and compositional characteristics. The older generation is Grs-rich $\left(\mathrm{Grs}_{66-65} \mathrm{Adr}_{35-28}\right)$. The fractures are filled by younger garnet dominated by Adr component $\left(\mathrm{Grs}_{37-23} \mathrm{Adr}_{74-55}\right)$. The zircon morphology ranges from rounded grains with crystal faces to partly rounded hypidiomorphic to idiomorphic prismatic grains. Cathodoluminescence images of their internal structure mostly show oscillatory zoning and sometimes patchy sector zoning (Fig. 5e). U-Pb ages for individual zircon 

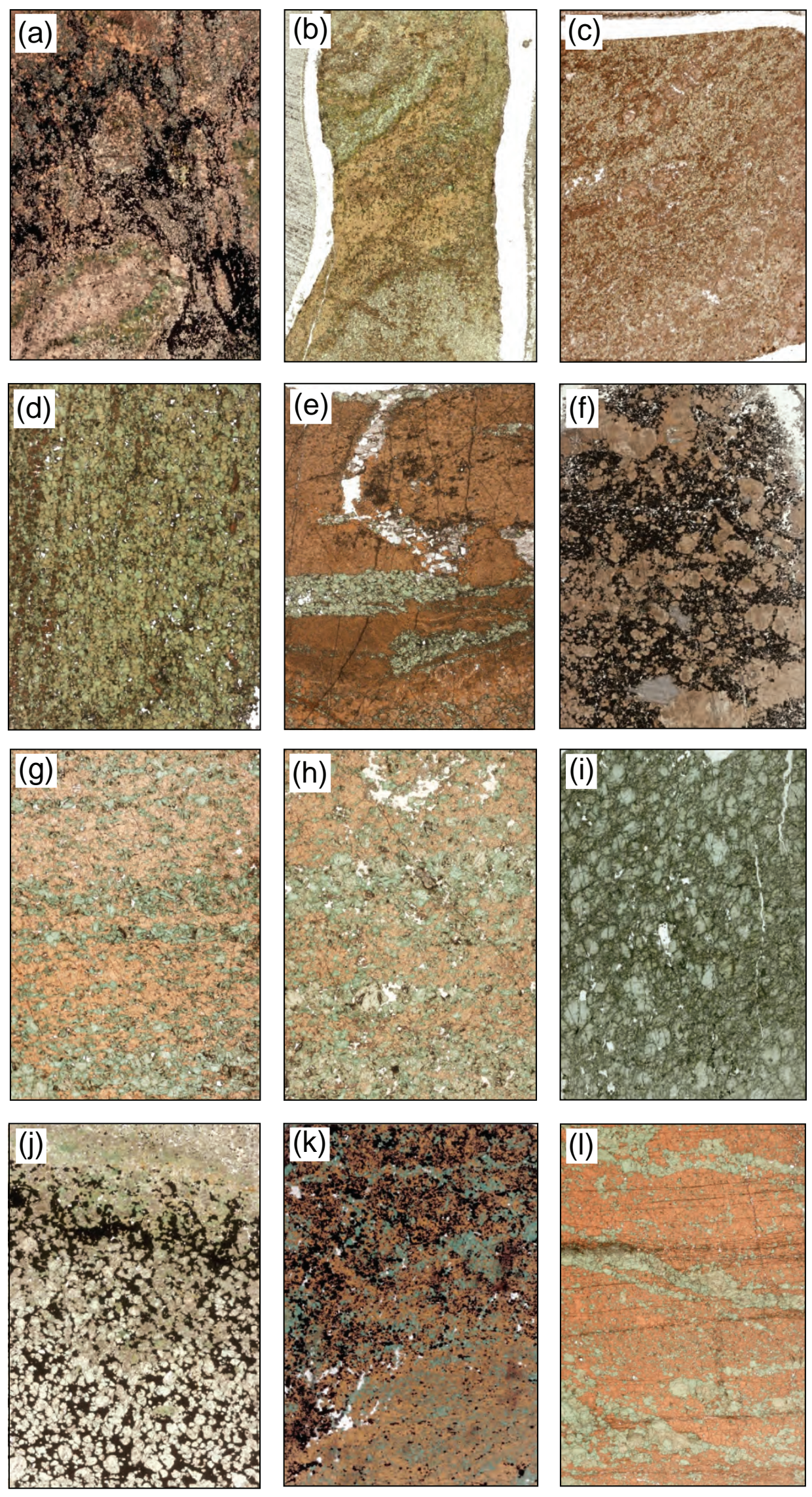

Fig. 2 Scanned thin-sections from studied localities. The Moldanubian Zone (Drosendorf Unit): a - Budeč (KM8/FV1), b - Budeč (KM8/ FV3), c - Vepřová (KM3/FV), d - Vlastějovice (KMVLA/FV1), e - Vlastějovice (KMVLA/FV2), f - Vlastějovice (KMVLA/FV3); the Moldanubian Zone (Gföhl Unit) - Rešice: g - KMRES2, h - KMRES3, i - KMRES5, j - KMRES6; the Kutná Hora Unit - Malešov: k - KMMAL/FV1, l - KMMAL/FV2. 
Tab. 5 Representative chemical analyses of pyroxenes from skarns of the Moldanubian Zone and the Kutná Hora Unit (wt. \% and apfu)

\begin{tabular}{|c|c|c|c|c|c|c|c|c|c|c|c|c|c|c|}
\hline \multirow{4}{*}{$\begin{array}{l}\text { location } \\
\text { sample } \\
\text { position }\end{array}$} & \multicolumn{8}{|c|}{ Moldanubian zone } & \multirow{2}{*}{\multicolumn{4}{|c|}{$\begin{array}{c}\text { Gföhl Unit } \\
\text { KMRES6 }\end{array}$}} & \multicolumn{2}{|c|}{ Kutná Hora Unit } \\
\hline & \multicolumn{4}{|c|}{ KMVLA/FV2 } & \multicolumn{4}{|c|}{ KMVLA/FV3 } & & & & & \multirow{3}{*}{$\begin{array}{c}\text { KMMAL/ } \\
\text { FV1 } \\
\text { core }\end{array}$} & \multirow{3}{*}{$\begin{array}{c}\text { KMMAL/ } \\
\text { FV2 } \\
\\
\text { rim }\end{array}$} \\
\hline & \multirow{2}{*}{$\begin{array}{l}\text { inclusion } \\
\text { core }\end{array}$} & \multicolumn{3}{|c|}{ inclusion } & \multirow[b]{2}{*}{ core } & \multirow[b]{2}{*}{ rim } & \multirow[b]{2}{*}{ core } & \multirow[b]{2}{*}{ rim } & \multicolumn{2}{|l|}{ at garnet } & \multicolumn{2}{|c|}{ profile } & & \\
\hline & & core & core & core & & & & & rim & core & core & rim & & \\
\hline \multicolumn{15}{|l|}{ (wt. \%) } \\
\hline $\mathrm{SiO}_{2}$ & 50.66 & 51.57 & 51.44 & 51.60 & 48.79 & 48.91 & 48.81 & 49.74 & 53.84 & 53.67 & 52.32 & 51.90 & 48.81 & 49.86 \\
\hline $\mathrm{TiO}_{2}$ & 0.04 & 0.02 & 0.00 & 0.01 & 0.03 & 0.03 & 0.03 & 0.01 & 0.00 & 0.02 & 0.00 & 0.00 & 0.00 & 0.06 \\
\hline $\mathrm{Cr}_{2} \mathrm{O}_{3}$ & 0.00 & 0.01 & 0.01 & 0.02 & 0.00 & 0.00 & 0.01 & 0.00 & 0.00 & 0.00 & 0.01 & 0.00 & 0.00 & 0.00 \\
\hline $\mathrm{Al}_{2} \mathrm{O}_{3}$ & 1.01 & 0.39 & 0.54 & 0.59 & 1.72 & 2.03 & 1.52 & 1.09 & 0.67 & 0.95 & 1.08 & 1.33 & 1.76 & 1.66 \\
\hline $\mathrm{FeO}$ & 18.34 & 16.75 & 17.16 & 16.96 & 22.57 & 22.47 & 26.10 & 25.36 & 11.32 & 10.69 & 17.72 & 17.26 & 23.44 & 21.62 \\
\hline $\mathrm{MnO}$ & 0.32 & 0.26 & 0.20 & 0.24 & 0.15 & 0.18 & 0.18 & 0.17 & 0.08 & 0.10 & 0.18 & 0.18 & 0.16 & 0.13 \\
\hline $\mathrm{MgO}$ & 6.35 & 7.86 & 7.38 & 7.58 & 4.18 & 4.18 & 3.28 & 3.66 & 12.71 & 12.86 & 9.53 & 9.54 & 3.81 & 5.93 \\
\hline $\mathrm{CaO}$ & 22.62 & 23.28 & 22.81 & 23.24 & 22.29 & 22.40 & 21.79 & 21.88 & 23.27 & 23.73 & 20.97 & 20.55 & 21.69 & 22.49 \\
\hline $\mathrm{Na}_{2} \mathrm{O}$ & 0.39 & 0.35 & 0.40 & 0.44 & 0.57 & 0.59 & 0.57 & 0.60 & 0.36 & 0.20 & 0.74 & 0.75 & 1.22 & 0.80 \\
\hline $\mathrm{K}_{2} \mathrm{O}$ & 0.00 & 0.00 & 0.03 & 0.00 & 0.03 & 0.00 & 0.03 & 0.00 & 0.00 & 0.01 & 0.01 & 0.00 & 0.00 & 0.01 \\
\hline Total & 99.73 & 100.49 & 99.95 & 100.67 & 100.33 & 100.80 & 102.32 & 102.51 & 102.25 & 102.22 & 102.57 & 101.51 & 100.89 & 102.54 \\
\hline$(\mathrm{apfu})^{*}$ & \multicolumn{14}{|c|}{ Number of ions on the basis of $6 \mathrm{O}$} \\
\hline $\mathrm{Si}$ & 1.99 & 1.99 & 2.00 & 1.99 & 1.93 & 1.93 & 1.92 & 1.94 & 1.98 & 1.97 & 1.96 & 1.96 & 1.92 & 1.91 \\
\hline $\mathrm{Ti}$ & 0.00 & 0.00 & 0.00 & 0.00 & 0.00 & 0.00 & 0.00 & 0.00 & 0.00 & 0.00 & 0.00 & 0.00 & 0.00 & 0.00 \\
\hline $\mathrm{Cr}$ & 0.00 & 0.00 & 0.00 & 0.00 & 0.00 & 0.00 & 0.00 & 0.00 & 0.00 & 0.00 & 0.00 & 0.00 & 0.00 & 0.00 \\
\hline $\mathrm{Al}$ & 0.05 & 0.02 & 0.03 & 0.03 & 0.08 & 0.09 & 0.07 & 0.05 & 0.03 & 0.04 & 0.05 & 0.06 & 0.08 & 0.07 \\
\hline $\mathrm{Fe}$ & 0.60 & 0.54 & 0.56 & 0.55 & 0.75 & 0.74 & 0.86 & 0.83 & 0.35 & 0.33 & 0.56 & 0.55 & 0.59 & 0.53 \\
\hline $\mathrm{Mn}$ & 0.01 & 0.01 & 0.01 & 0.01 & 0.01 & 0.01 & 0.01 & 0.01 & 0.00 & 0.00 & 0.01 & 0.01 & 0.00 & 0.01 \\
\hline $\mathrm{Mg}$ & 0.37 & 0.45 & 0.43 & 0.44 & 0.25 & 0.25 & 0.19 & 0.21 & 0.70 & 0.70 & 0.53 & 0.54 & 0.34 & 0.22 \\
\hline $\mathrm{Ca}$ & 0.95 & 0.96 & 0.95 & 0.96 & 0.95 & 0.94 & 0.92 & 0.92 & 0.92 & 0.94 & 0.84 & 0.83 & 0.92 & 0.91 \\
\hline $\mathrm{Na}$ & 0.03 & 0.03 & 0.03 & 0.03 & 0.04 & 0.05 & 0.04 & 0.05 & 0.03 & 0.01 & 0.05 & 0.06 & 0.06 & 0.09 \\
\hline K & 0.00 & 0.00 & 0.00 & 0.00 & 0.00 & 0.00 & 0.00 & 0.00 & 0.00 & 0.00 & 0.00 & 0.00 & 0.00 & 0.00 \\
\hline $\mathrm{X}_{\mathrm{Fe}}$ & 0.62 & 0.54 & 0.57 & 0.56 & 0.75 & 0.75 & 0.82 & 0.80 & 0.33 & 0.32 & 0.51 & 0.50 & 0.78 & 0.67 \\
\hline
\end{tabular}

grains range from 485 to $750 \mathrm{Ma}$. Individual data are $c$. 2.0 Ga and c. 3.1 Ga (Fig. 7c-d).

\subsubsection{Vlastějovice, garnet-magnetite skarn KMVLA/FV3}

Garnet and magnetite are the most abundant minerals in skarns with massive structure (Fig. 2f). The garnet exhibits extremely complicated internal patchy structure. The darker parts (in BSE) correspond to the prevailing grossular component, while the lighter spots contain higher proportions of andradite (Fig. 3b). Magnetite is disseminated or forms cubic inclusions in the garnet, corresponding to 20-30 vol. \% in the sample. The zircon grains are light beige and mostly rounded or slightly elongated (Figs $4 c-d$ ). Cathodoluminescence images show welldeveloped, mostly oscillatory zoning (Fig. 5f). U-Pb dating of the zircon (59 grains) yielded a wide range of ages of c. 0.31-2.4 Ga (Fig. 7 e-f). The corresponding age spectrum has a main peak at c. $520 \mathrm{Ma}$, minor peaks at $c .370 \mathrm{Ma}$ and c. 1.7-2.0 Ga and individual data at $c$. $320 \mathrm{Ma}, 750 \mathrm{Ma}, 2.0 \mathrm{Ga}$ and $2.4 \mathrm{Ga}$.

\subsection{The Moldanubian Zone (Gföhl Unit)}

Skarn occurrences at the Rešice locality are associated with calc-silicate rocks and amphibolites and are mostly layered or partly banded conformably with the surrounding felsic gneiss or advanced migmatite. Relics of older structures are common in skarns. The following rock types were studied: garnet-clinopyroxene, clinopyroxene and magnetite skarns.

\subsubsection{Rešice, garnet-clinopyroxene skarn KMRES2}

The skarn exhibits a banded structure (Fig. 2g). The garnet belongs mainly to the grossular-andradite series $\left(\mathrm{Grs}_{57-55} \operatorname{Prp}_{1} \mathrm{Alm}_{9-7} \mathrm{Sps}_{2-1} \mathrm{Adr}_{34-21}\right)$. Garnets are surrounded by plagioclase-clinopyroxene coronas (Fig. 3c). The 

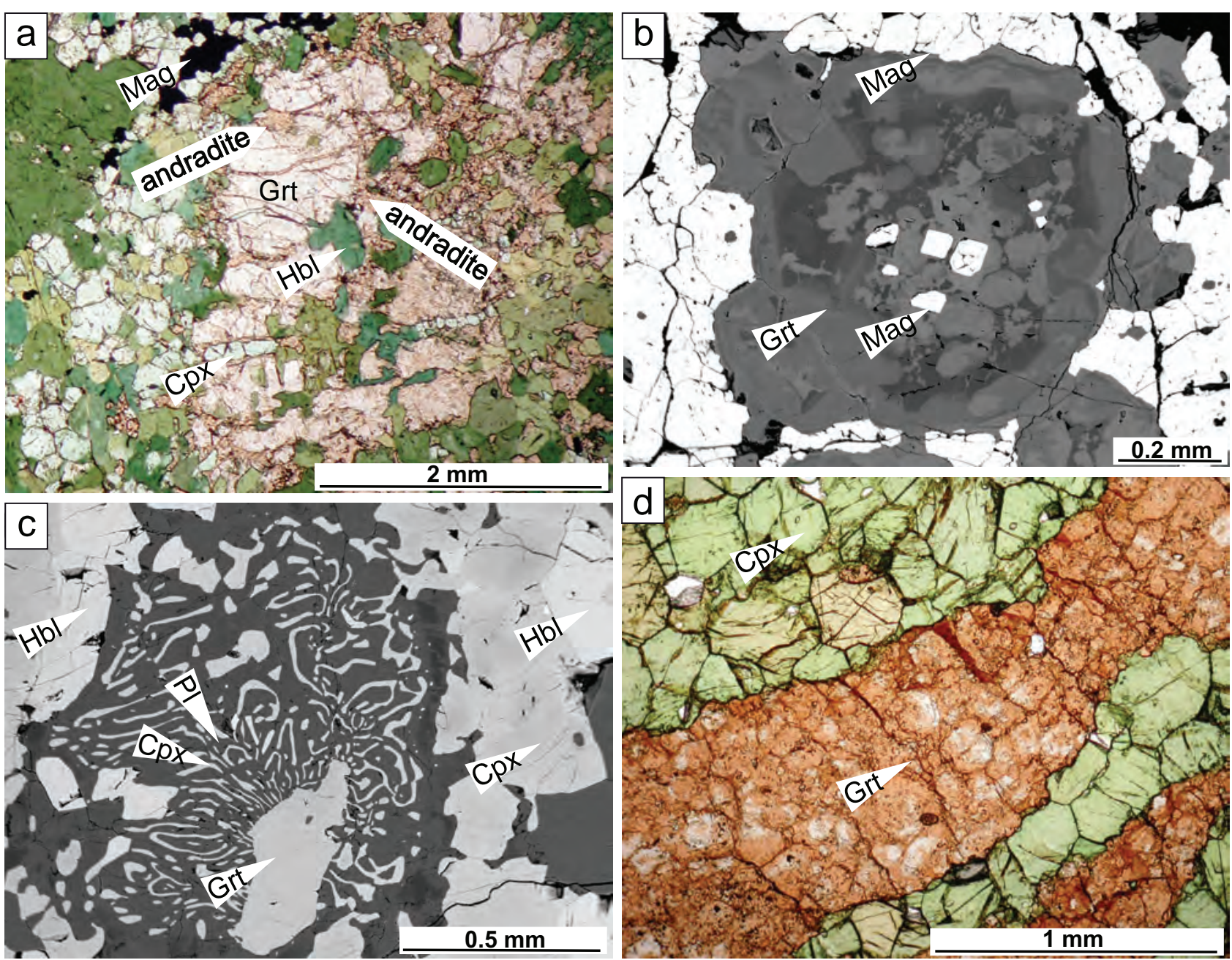

Fig. 3 Representative photomicrographs of studied skarns (a, d - plane polarized light, b, c - back-scattered electrons). a - Budeč (KM8/FV1): Mag + Cpx + Grt skarn, fractures in older Grs-rich skarn are filled by younger andradite; b -Vlastějovice (KMVLA/FV3): Grt-Mag skarn, inhomogeneous garnet with cubic inclusions of magnetite; $\mathbf{c}-$ Rešice (KMRES2): Cpx + Hbl + Grt skarn, garnet is surrounded by a decompression Pl-clinopyroxene corona; d -Malešov (KMMAL/FV2): banded Grt-Cpx skarn. Mineral abbreviations after Kretz (1983).

clinopyroxene composition corresponds to hedenbergite. Both epidote and plagioclase are secondary. Pertold et al. (1997) described disintegration of titanite (Al-bearing) to titanite-plagioclase symplectite at this locality. Zircon forms euhedral prisms with weak zoning (Fig. $5 \mathrm{~g}$ ). The ages for 40 grains vary from 340 to $360 \mathrm{Ma}$ with individual data of c. 390-415 Ma (Fig. 8a).

\subsubsection{Rešice, garnet-clinopyroxene skarn KMRES3}

The main mineral is garnet, accompanied by less abundant clinopyroxene - hedenbergite (Fig. 2h). Garnets form inhomogeneous grains ( $\mathrm{Grs}_{62-54} \operatorname{Prp}_{1} \mathrm{Alm}_{13-10} \mathrm{Sps}_{1} \mathrm{Adr}_{30-25}$ ). Pyroxene, plagioclase, quartz and opaque minerals form inclusions in garnets. The morphology of zircon ranges from rounded grains with crystal faces to hypidiomorphic grains. Cathodoluminescence images reveal metamict do- mains (Fig. 5h). The $\mathrm{U}-\mathrm{Pb}$ ages for the individual zircon ages range from 350 to $450 \mathrm{Ma}$ (Fig. 8b).

\subsubsection{Rešice, clinopyroxene skarn KMRES5}

Pyroxene skarn (Fig. 2i) was taken from the ore body. Clinopyroxene (diopside) generally exhibits no zoning; replacement by secondary amphibole is common. Titanite, zircon and apatite are common accessories. Light pink to brown zircons are rounded and also elongated (Fig. 4e). Cathodoluminescence images show metamict domains (Fig. 5i). The U-Pb ages of zircons from this mineralized skarn yielded a concordia age of $331 \pm 2 \mathrm{Ma}$ (Fig. 8c).

\subsubsection{Rešice, magnetite skarn KMRES6}

This sample (Fig. 2j) was taken from a massive magnetite layer. Magnetite is the main mineral, corresponding to 40 
60 vol. \%. Replacement of clinopyroxene (diopside) by secondary amphibole is common. Garnet is a very rare mineral $\left(\mathrm{Grs}_{22-19} \operatorname{Prp}_{17-16}\right.$ $\left.\mathrm{Alm}_{57-51} \mathrm{Sps}_{2-1} \mathrm{Adr}_{11-8}\right)$. Two types of zircon were observed (Fig. 4f). The first type is light orange or pink in colour. Its morphology ranges from rounded grains with crystal faces through partly rounded hypidiomorphic to idiomorphic prismatic grains with oscillatory zoning. The second type of zircon is medium brown to dark brown. Cathodoluminescence images show patchy zoning (Fig. 5j). Sixty-seven $\mathrm{U}-\mathrm{Pb}$ analyses of zircons from this sample yielded equivalent and concordant results with a concordia age of $324 \pm 3 \mathrm{Ma}$ (Fig. 8d).

\subsection{The Kutná Hora Unit}

The Malešov skarn body is located in the structurally highest part of the Kutná Hora Unit, the Malín Sub-unit, composed of polymetamorphic migmatites and two-mica kyanite migmatites. The skarn body $(\sim 200 \times 1000 \mathrm{~m})$ forms an asymmetric antiformal structure. The internal planar structures of the skarn are defined by alternating bands rich in garnet or pyroxene and are oriented discordantly in relation to the metamorphic planar fabric of the enclosing rocks (Pertoldová et al. 2009). The geological situation is shown in the Czech Geological Survey map at the scale $1: 25,000$ (Štědrá et al. 2011).

\subsubsection{Malešov, garnet-magnetite skarn KMMAL/FV1}

This is a fine-grained rock with massive structure (Fig. 2k). The main minerals are garnet and magnetite (40-50 vol. \%). Garnets are weakly zoned $\left(\mathrm{Grs}_{56-17} \operatorname{Prp}_{5-1} \mathrm{Alm}_{22-9} \mathrm{Sps}_{5-1}\right.$ $\left.\mathrm{Adr}_{78-33}\right)$. Less abundant clinopyroxene (hedenbergite) is partly replaced by amphibole. The sample contains light grey, clear anhedral zircons with rare crystal faces (Fig. 4g). Cathodoluminescence images show mostly patchy zoning (Fig. 5k) and $58 \mathrm{U}-\mathrm{Pb}$ analyses of these zircon domains yielded a concordia age of $338 \pm 2$ Ma (Fig. 8e). et al. (1981)
Tab. 6 Representative chemical analyses of amphiboles and plagioclases from skarns of the Moldanubian Zone and the Kutná Hora Unit (wt. \% and apfu)

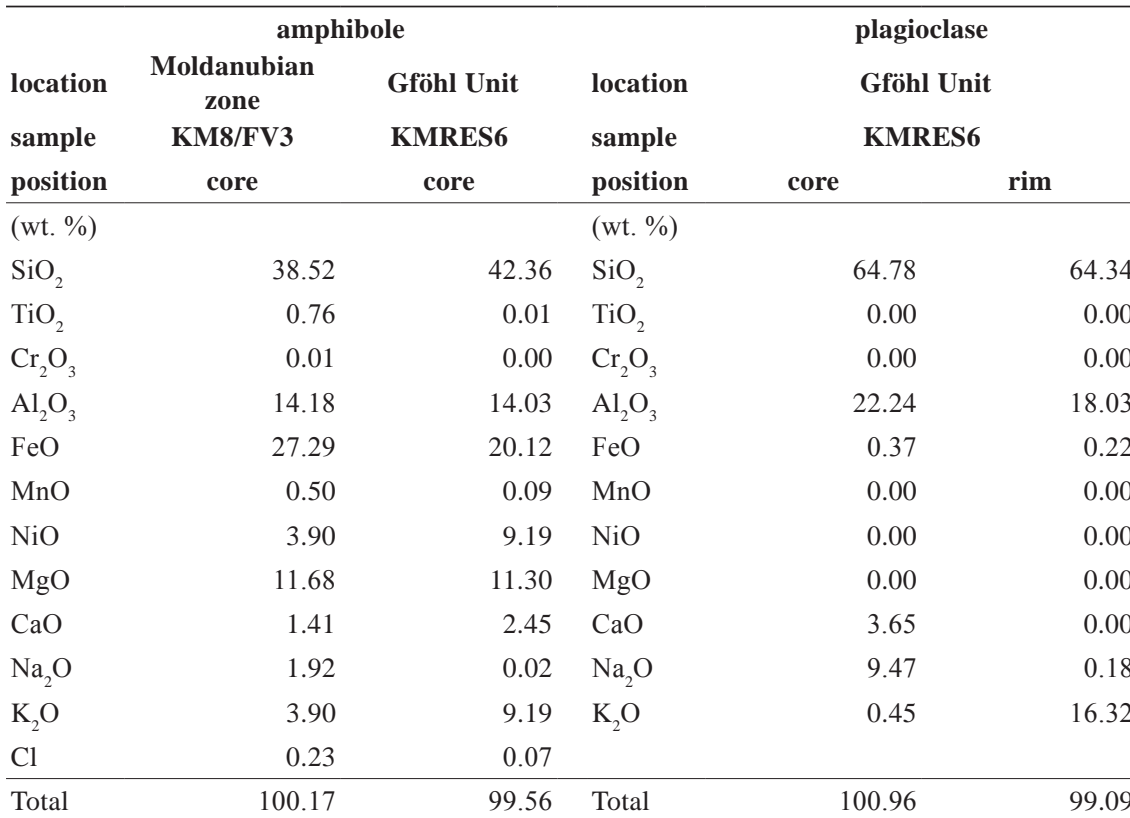

$(\mathrm{apfu}) * \quad$ Number of ions on the basis of $23 \mathrm{O} \quad(\mathrm{apfu}) * *$ Number of ions on the basis of $8 \mathrm{O}$

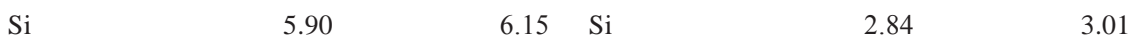

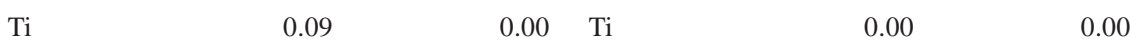

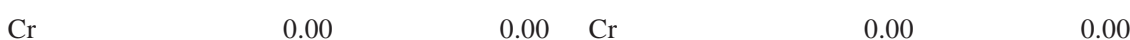

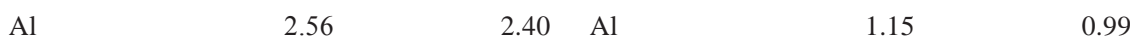

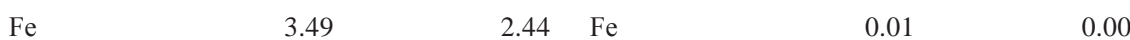

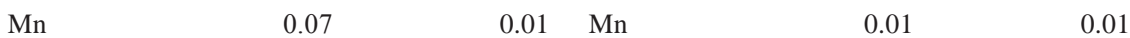

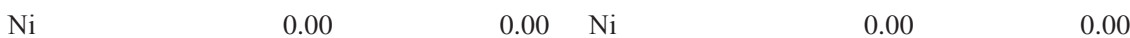

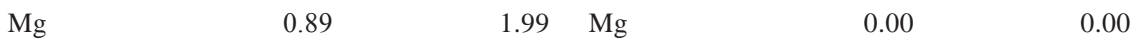

$\begin{array}{lllll}\mathrm{Ca} & 1.92 & 1.76 & \mathrm{Ca} & 0.00\end{array}$

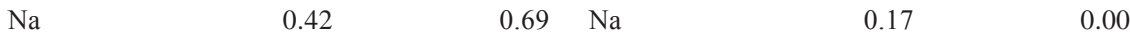

\begin{tabular}{llllll} 
K & 0.38 & 0.00 & $\mathrm{~K}$ & 0.80 & 0.02 \\
\hline
\end{tabular}

$\begin{array}{llllll}\mathrm{Cl} & 0.06 & 0.02 & \mathrm{Ab} & 0.17 & 0.00\end{array}$

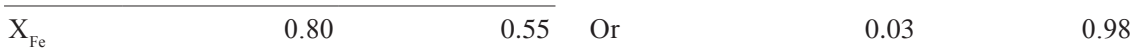

* recalculated after Richard and Clarke (1990), $\mathrm{Fe}^{2+} / \mathrm{Fe}^{3+}$ was estimated according to Robinson

** recalculated after Deer at al (2001)

\subsubsection{Malešov, garnet-clinopyroxene skarn KMMAL/FV2}

The skarn exhibits banded structure (Fig. 21). The major minerals, garnet and clinopyroxene, are accompanied by less abundant plagioclase. Garnet or clinopyroxene bands often exhibit irregular folding, swelling to elongated lenses and schlieren (Fig. 3d). Garnets are weakly zoned and partly replaced by younger epidote. Their inclusions comprise pyroxene, magnetite or titanite. Clinopyroxenes are unzoned and their composition corresponds to hedenbergite. Subhedral zircons exhibit various forms (Fig. 4h) with oscillatory zoning (Fig. 5l). The U-Pb 

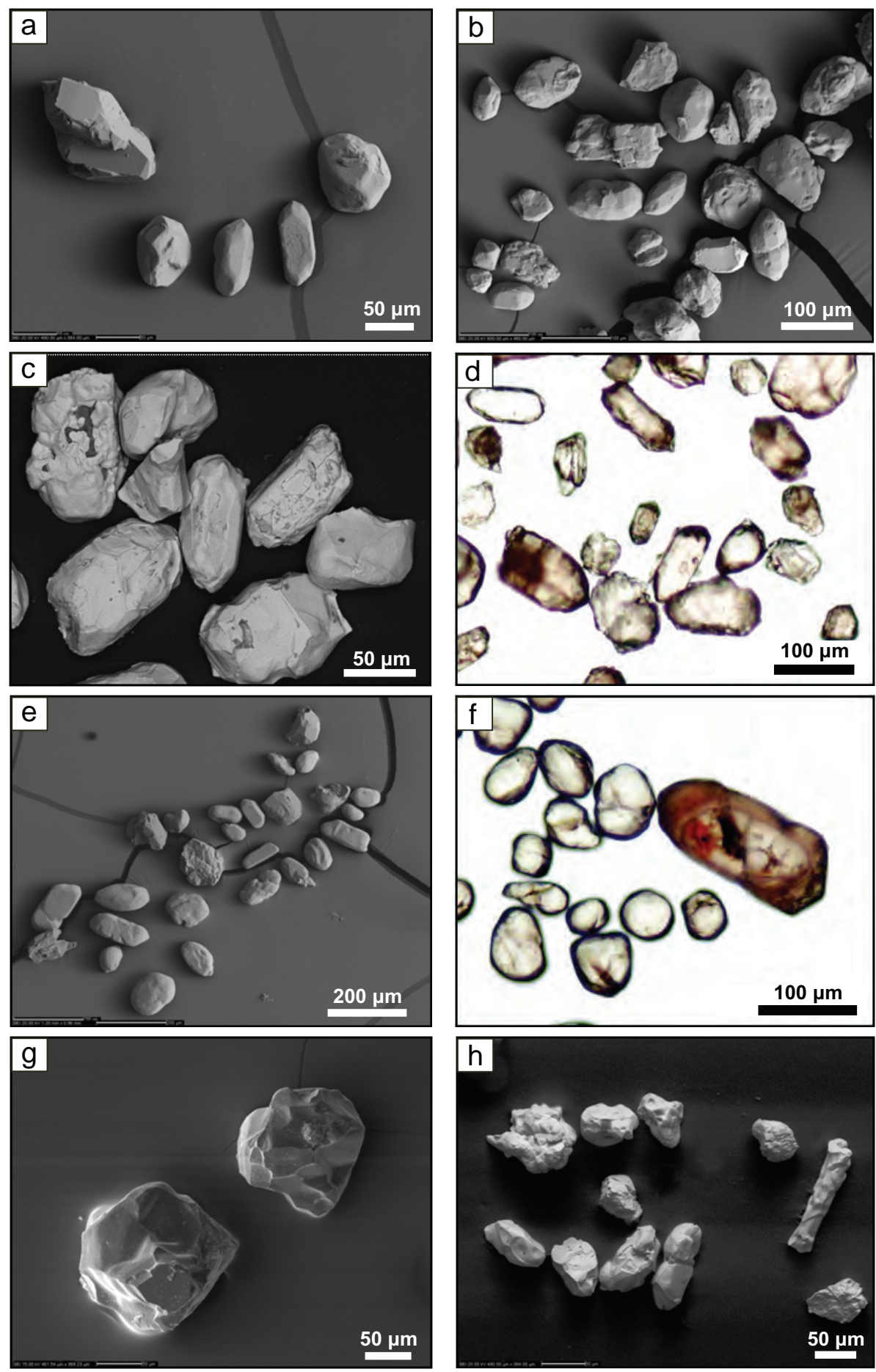

Fig. 4 Photographs of zircons showing crystallization textures $(\mathrm{a}-\mathrm{e}, \mathrm{g}-\mathrm{h}-\mathrm{SEI}$ secondary electron image; $d, f-$ optical microscope). a - Budeč (KM8/FV3); b - Vepřová (KM3/FV); c - Vlastějovice (KMVLA/FV3); d - Vlastějovice (KMVLA/FV3); e - Rešice (KMRES5); f - Rešice (KMRES6); g - Malešov (KMMAL/FV1); $\mathbf{h}$ - Malešov (KMMAL/FV2).

dating yielded various ages in the range of 330-620 Ma (Fig. 8f).

\section{Discussion of zircon ages}

The new $\mathrm{U}-\mathrm{Pb}$ ages of zircon in skarns, combined with the previous dating at the Svratouch locality in the Svratka Unit (Pertoldová et al. 2009), tend to concentrate into four groups: (1) Neoarchaean to Neoproterozoic (Group A; sparse ages between 3000 and $800 \mathrm{Ma}$ ), (2) strong peaks at the Neoproterozoic-Cambrian boundary (Group $\mathrm{B}$; maxima at $600,560,550$, and $520 \mathrm{Ma}$ ), (3) late Cambrian to early Devonian (Group C; sparse ages between 505 and $406 \mathrm{Ma}$ ), and (4) strong maxima of early Carboniferous ages (Group D; 338, 331, $324 \mathrm{Ma}$ ). The different $\mathrm{U}-\mathrm{Pb}$ zircon age groups of the studied samples are listed in Tab. 7 and plotted in Fig. 9. 


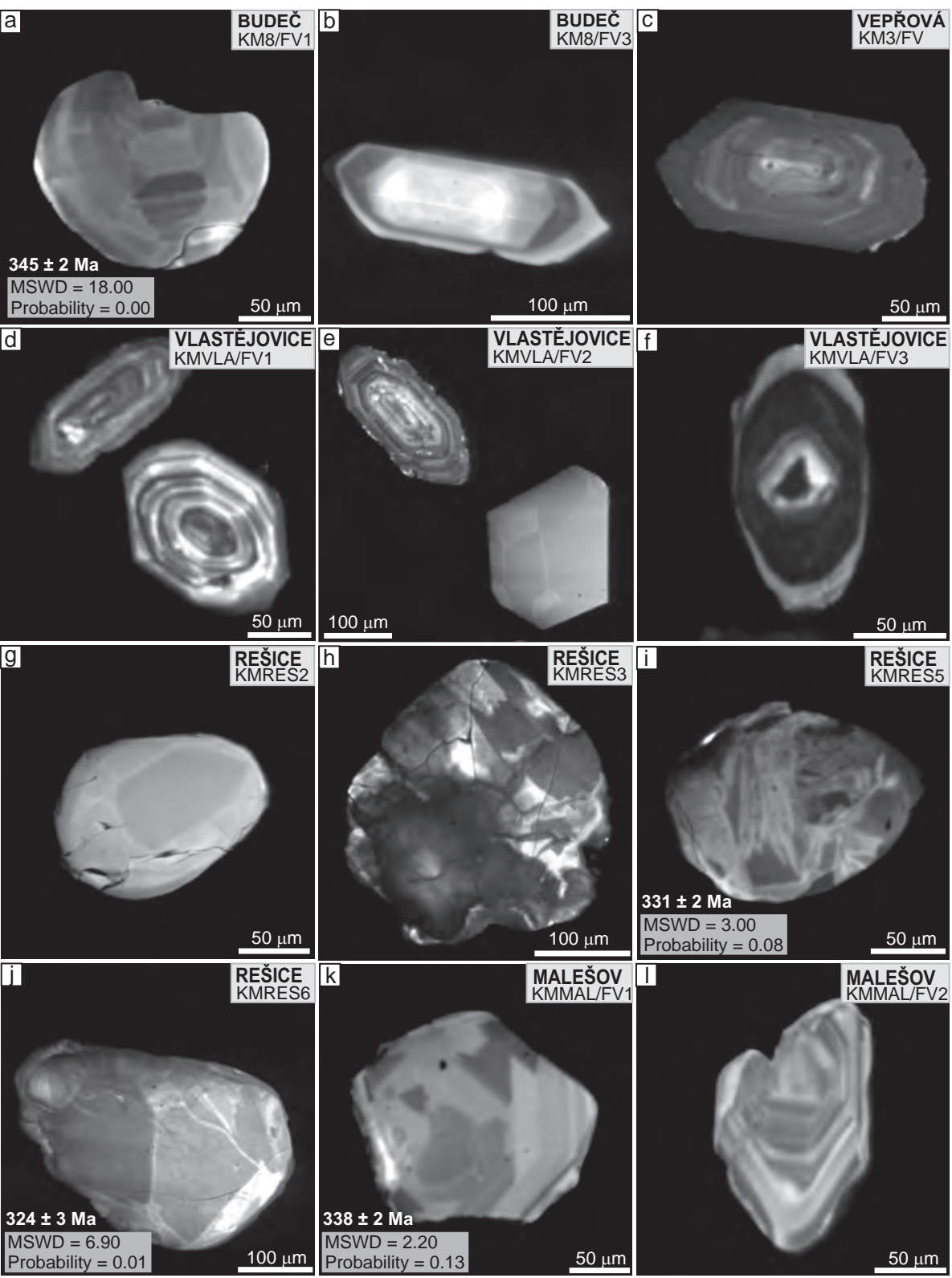

Fig. 5 Cathodoluminescence images of representative zircons: a - Budeč (KM8/FV1); b - Budeč (KM8/FV3); c - Vepřová (KM3/FV); d - Vlastějovice (KMVLA/FV1); e - Vlastějovice (KMVLA/FV2); f - Vlastějovice (KMVLA/FV3); g - Rešice (KMRES2); h - Rešice (KMRES3); i - Rešice (KMRES5); j - Rešice (KMRES6); $\mathbf{k}$ - Malešov (KMMAL/FV1); l - Malešov (KMMAL/FV2).

The Group A zircons could be interpreted as detrital grains from the pre-Cadomian basement rocks because of the great spread of their ages. They are present in samples, in which the Group B zircons are dominant.

The Group B zircons in the Svratka Unit are interpreted as detrital grains (sedimentary or volcanogenic) suggesting late Neoproterozoic (Ediacaran) to early Cambrian depositional age of the Svratka skarn precursor, because their host gneisses were intruded by metagranites of Cambrian age (515 $\pm 9 \mathrm{Ma}$; Schulmann et al. 2005). The Group B zircons are preserved also in some Moldanubian skarn samples without magnetite mineralization (Budeč, Vepřová, Vlastějovice) as well as in the Malešov non-mineralized skarn (Kutná Hora Unit).
The Group $C$ zircons occur in the non-mineralized samples of the Moldanubian Zone (Budeč, Vlastějovice and Rešice) and also in the Kutná Hora Unit (Malešov). Their wide age range (late Cambrian to early Devonian) points to detrital precursor of younger than early Devonian age. From this perspective, which excludes metamorphic modifications, the zircons most likely had the source in disintegrated rocks of early Palaeozoic age. For example, the early Palaeozoic bimodal magmatism is widespread throughout the Variscan orogenic belt in Europe. It was related with a regional extension (continental rifting) and mantle plume upwelling during the northern Gondwana break-up (e.g. Crowley et al. 2000; Linnemann et al. 2008). These magmatic rocks were a possible source for younger sedimentary sequences of the 


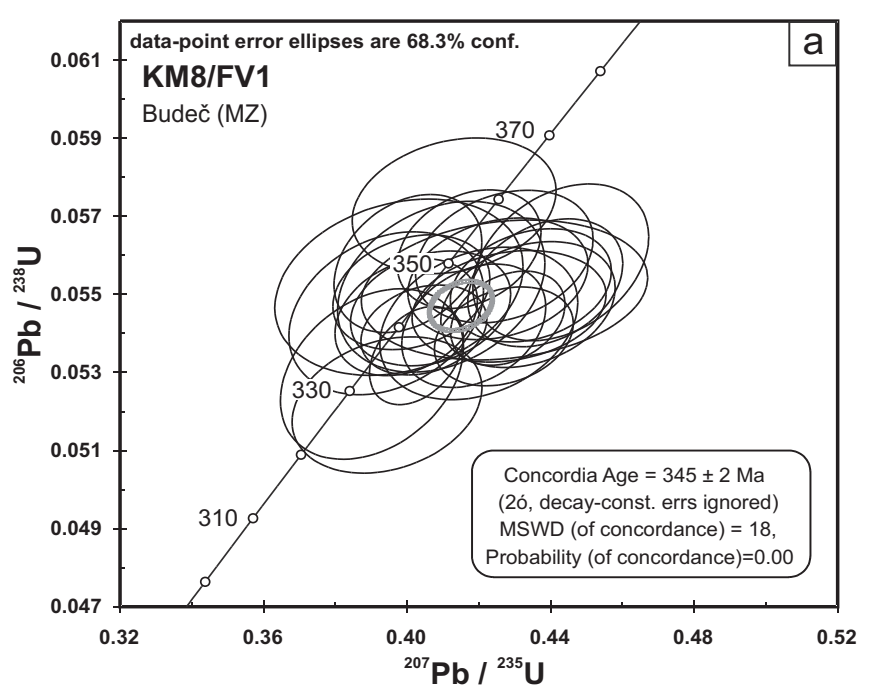

Teplá-Barrandian Zone (Drost et al. 2011) and in part also for protoliths of Moldanubian metasedimentary rocks (Košler et al. 2014). In addition, orthogneisses and deformed granitoids intruding the Moldanubian sequence with Ordovician protoliths were identified by Vrána and Kröner (1995), Povondra and Vrána (1996), Teipel et al. (2004) and Friedl et al. (2004).

On the other hand, the accumulating general knowledge of possible zircon recrystallization at the presence of HT melt or fluids (e.g. Harley et al. 2007; Villa 2010), with several related examples from the Bohemian Massif (e.g. Roberts and Finger 1997; Tropper et al. 2005; Janoušek et al. 2006b; Bröcker et al. 2010; Nahodilová et al. 2014), point to zircon crystallization along decompression path of HT/HP rocks and to
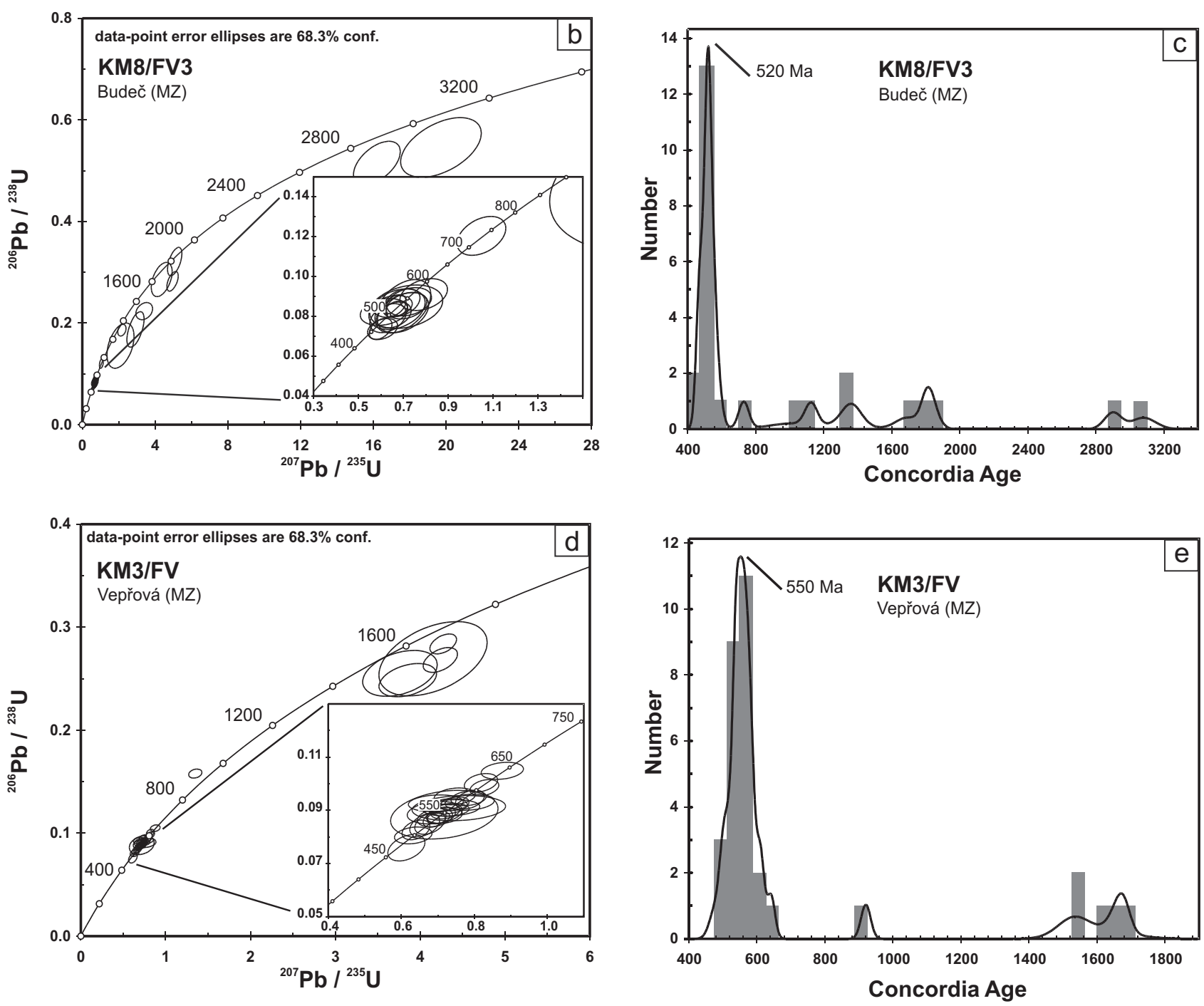

Fig. 6 Concordia diagram for concordant populations of detrital zircons and frequency curves for sample KM8/FV1from Budeč (a) and concordia diagrams for concordant populations of detrital zircons and frequency curves and histograms of zircon ages from Budeč (b, c - KM8/FV3) and Vepřová (d, e - KM3/FV). 

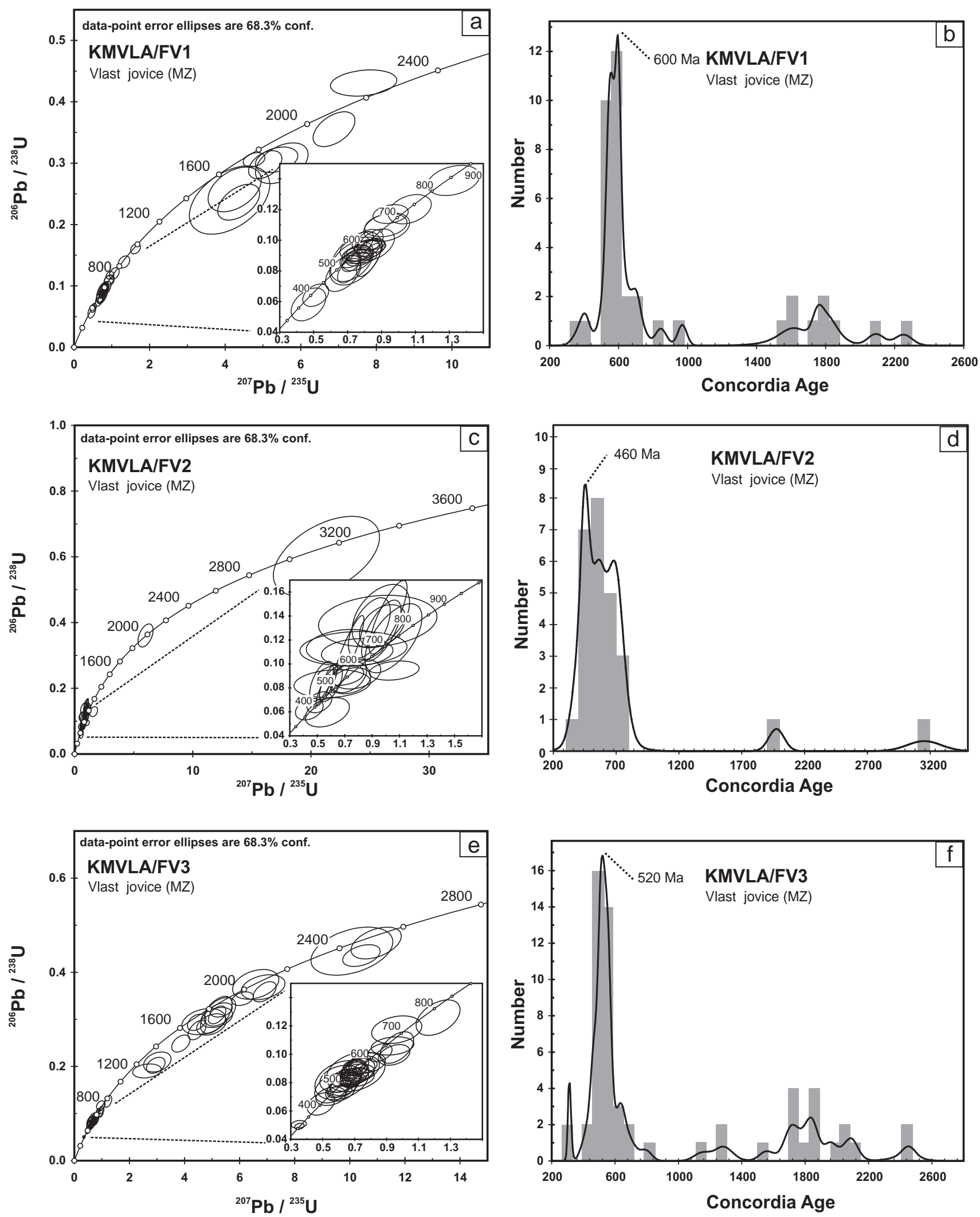

Fig. 7 Concordia diagrams for concordant populations of detrital zircons and frequency curves and histograms of zircon ages for samples from Vlastějovice (a, b - KMVLA/FV1; c, d - KMVLA/ FV2 and e, f - KMVLA/FV3). 

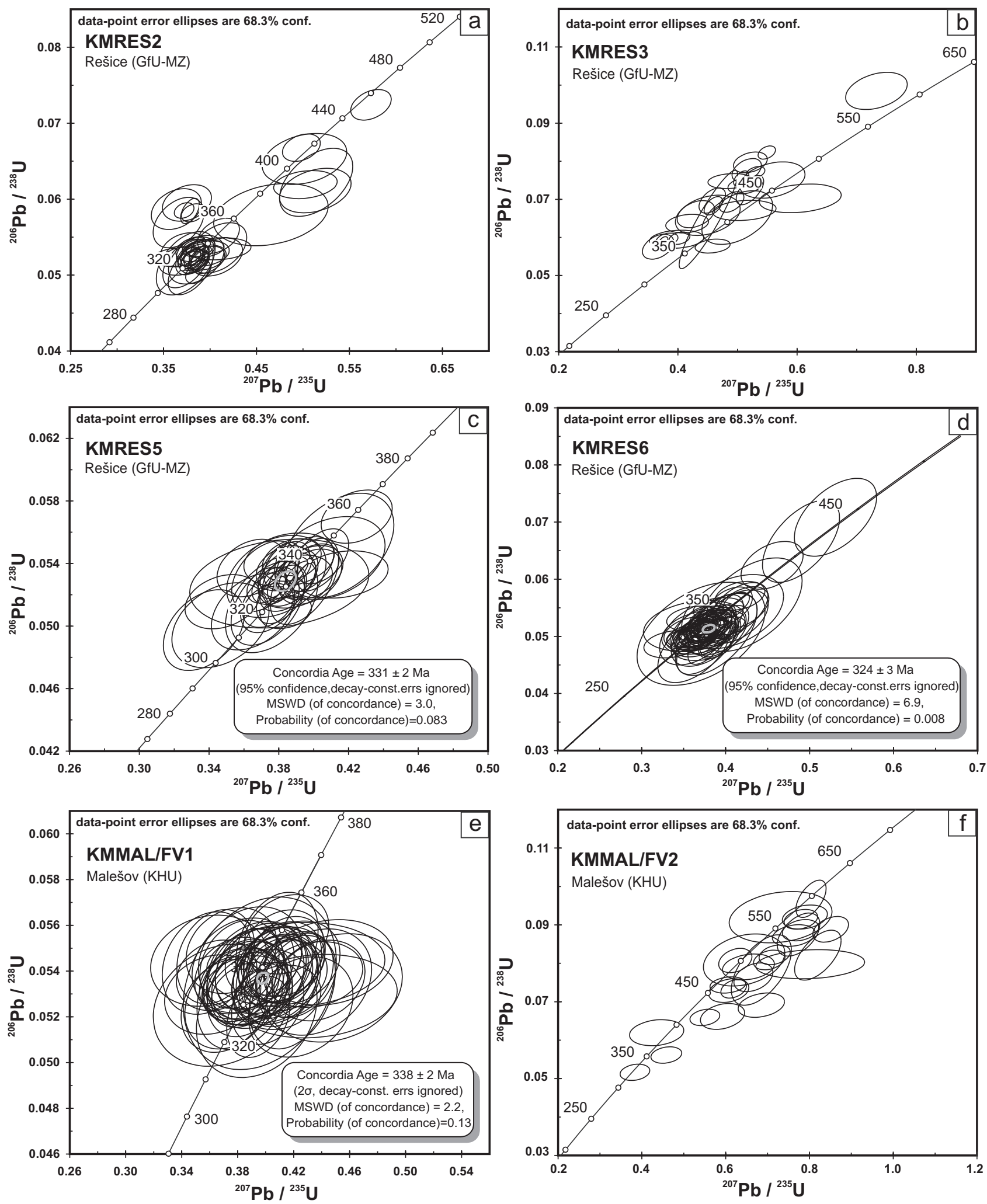

Fig. 8 Concordia diagrams for concordant populations of detrital zircons for samples from Rešice (a - KMRES2; b - KMRES3; c - KMRES5; d- KMRES6) and Malešov (e - KMMAL/FV1 and $\mathbf{f}-\mathrm{KMMAL/FV2).}$ 
Tab. $7 \mathrm{U}-\mathrm{Pb}$ zircon age groups in studied samples from the Moldanubian Zone, Kutná Hora and Svratka units

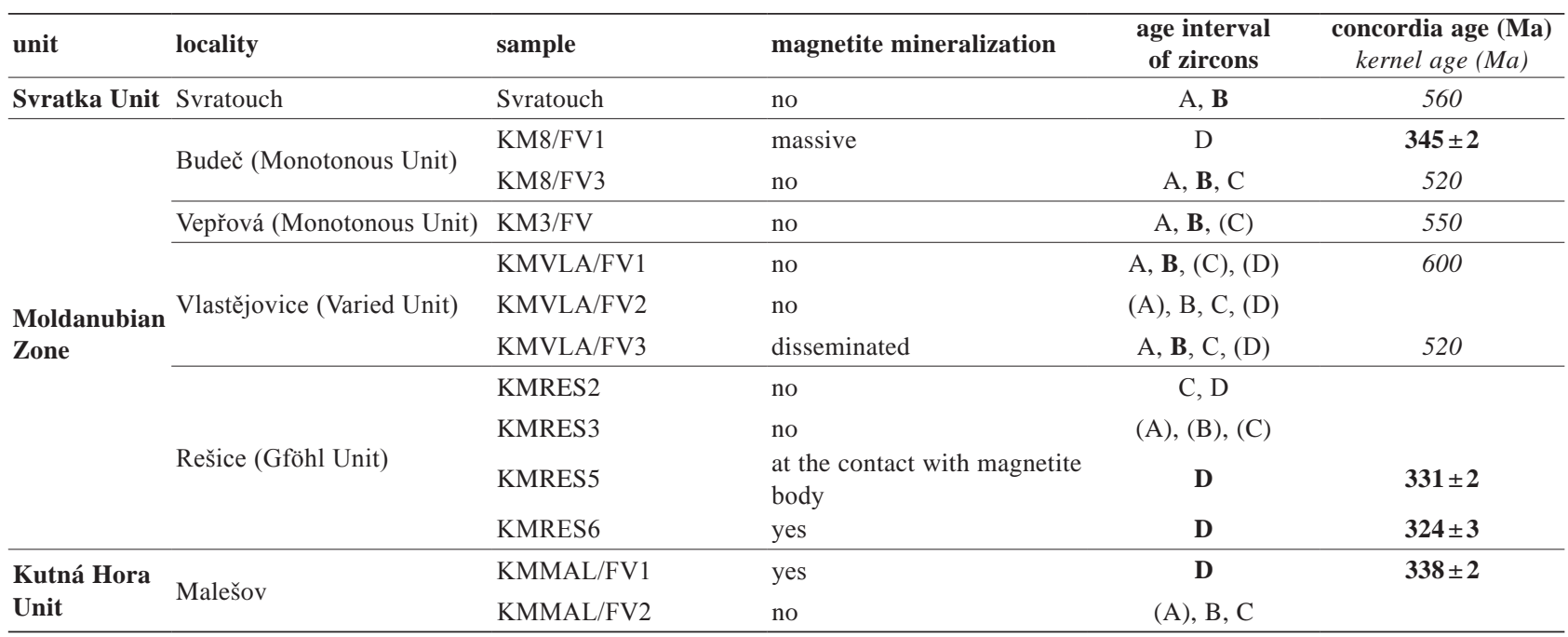

Notes:

Importance: $\mathbf{X}$ major ages, $\mathrm{X}$ - minor ages, $(\mathrm{X})$ - occasional ages

$\mathrm{A}=$ Neoarchaean to Proterozoic ages (sparse between 3000 and $800 \mathrm{Ma}$ )

$\mathrm{B}=$ Neoproterozoic to Cambrian ages (maxima at 600,560, 550, and $520 \mathrm{Ma}$ )

$\mathrm{C}=$ Late Cambrian to Early Devonian ages (sparse between 505 and $406 \mathrm{Ma}$ )

$\mathrm{D}=$ Early Carboniferous ages (338, 331, $324 \mathrm{Ma})$

variable $\mathrm{Pb}$ loss during high-grade metamorphism and attendant partial recrystallization/resetting of zircons. Therefore the Group $\mathrm{C}$ zircons could in fact represent Group B or Group A zircons modified to various degrees by metamorphic and/or hydrothermal processes.

In such an interpretation the skarn precursors of the Moldanubian Zone, Svratka and Kutná Hora units would have originated at probably Neoproterozoic-Cambrian boundary. The skarns and their zircons underwent larger or smaller metamorphic/hydrothermal modifications, together with their host rocks, especially strong in the early Carboniferous times. Before a more detailed study on the zircons in the skarns will be done, we have to admit that there are two interpretations of their protolith age: either Devonian or Neoproterozoic to early Cambrian.

The Group D zircons of early Carboniferous ages dominate the Moldanubian skarn samples with magnetite mineralization (Budeč and Rešice) and the Malešov magnetite skarn (Kutná Hora Unit). They are

Fig. 9 Summary histograms of $\mathrm{U}-\mathrm{Pb}$ zircon age groups in studied samples. also present in the Rešice (Gföhl Unit) sample without magnetite mineralization. Their age coincides with the Variscan HT metamorphism associated with anatexis or, possibly, also with the later migration of post-metamorphic fluids (Jawecki 1996; Drahota et al. 2005). Thus these zircons are likely of metamorphic or/and post-metamorphic origin, similarly as in the case of Moldanubian metasedimentary rocks (Košler et al. 2014).

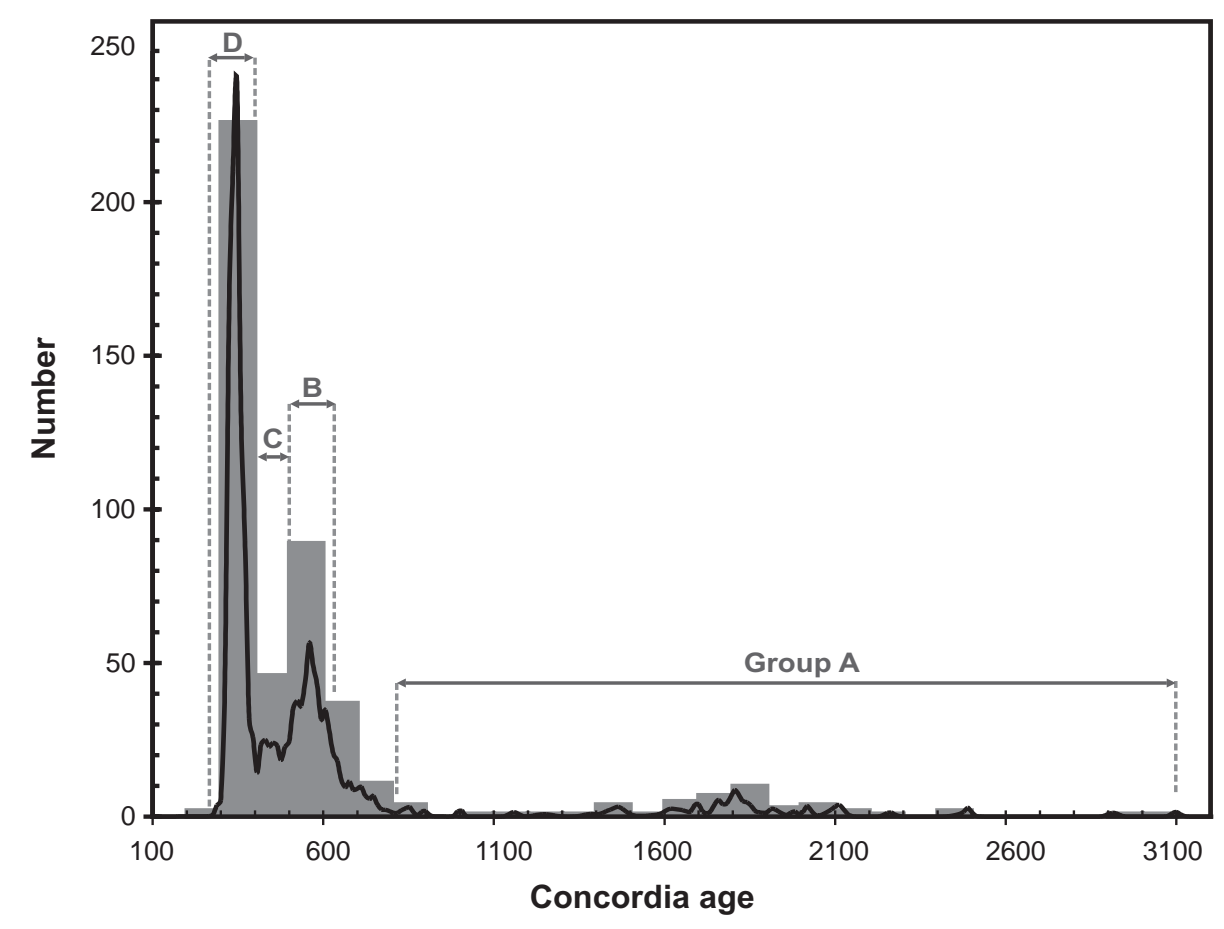




\section{Conclusions}

New LA-ICP-MS zircon U-Pb data on skarns from the Moldanubian Zone, Kutná Hora and Svratka units are heterogeneous and apparently range in age from Neoarchean to late Palaeozoic (3.1 Ga to $310 \mathrm{Ma}$ ). This geochronological pattern is a result of various detrital sources subsequently affected by metamorphic overprint. The oldest Neoarchean to Neoproterozoic ages are interpreted as detrital grains from pre-Cadomian basement. Strong peaks of zircon ages with maxima at $600,560,550$, and $520 \mathrm{Ma}$ were found in skarn samples without magnetite mineralization from the Moldanubian Zone, the Svratka and Kutná Hora units. Ages of this zircon population are interpreted as detrital in origin. Late Cambrian to early Devonian zircon ages occur in non-mineralized samples of the Moldanubian Zone and also in the Kutná Hora Unit. Two interpretations of the origin of zircon are possible: (1) zircons have the source in disintegrated rocks of early Paleozoic age or (2) originally detrital older zircons were overprinted/variably reset by metamorphic and hydrothermal processes. The strong maxima of early Carboniferous ages from the skarn samples with magnetite mineralization from all localities as well as from the Rešice (Gföhl Unit) sample lacking it are interpreted as being of metamorphic origin or associated with the later migration of post-metamorphic fluids.

Acknowledgements. This research was supported by the Internal Research Project No. 328800 of the Czech Geological Survey (to J. Pertoldová) and also in part by a scholarship grant Österreich-Tschechien (to K. Verner). We are indebted to Stanislav Vrána and Radmila Nahodilová for their helpful discussions and constructive comments. Madeleine Štulíková is thanked for revision of the English. We appreciate the help of Editor Gernold Zulauf and reviews by Axel Gerdes, Jiř́ Žák and an anonymous reviewer, which contributed to improving the manuscript. Last but not least, we thank editor-in-chief Vojta Janoušek for his careful editorial work.

Electronic supplementary material. The analytical data obtained by LA ICP-MS U-Pb zircon dating in the Moldanubian Zone (Drosendorf Unit), in the Moldanubian Zone (Gföhl Unit) and in the Kutná Hora Unit (Tabs S1-S3) and wholerock geochemical data (Tab. S4) are available online at the Journal web site ((http://dx.doi.org/10.3190/jgeosci.181)

\section{References}

Baker T, van Achterberg E, Ryan CG, LANG JR (2004) Composition and evolution of ore fluids in a magmatichydrothermal skarn deposit. Geology 32: 117-120
Breiter K, Čopjaková R, Gabašová A, ŠKoda R (2005) Chemistry and mineralogy of orthogneisses in the northeastern part of the Moldanubicum. J Czech Geol Soc 50: 81-94

Bröcker M, Klemd R, Kooljman E, Berndt J, Larionov AN (2010) Zircon geochronology and trace element characteristics of eclogites and granulites from the Orlica-Śnieżnik Complex, Bohemian Massif. Geol Mag 147: 339-362

Buriánek D, Verner K, Hanžl P, Krumlová H (2009) Petrochemical and microstructural comparison between Cambro-Ordovician metagranites and migmatites of the Svratka Unit and the Orlice-Sněžník Unit. J Geosci 54: 181-200

BURT DM (1982) Skarn deposits - historical bibliography through 1970. Econ Geol 77: 755-763

Carswell DA, O'Brien PJ (1993) Thermobarometry and geotectonic significance of high-pressure granulites: examples from the Moldanubian Zone of the Bohemian Massif in Lower Austria: J Petrol 34: 427-459

СhÁb J, StrÁník Z, Eliáš M (2007) The Geological Map of the Czech Republic 1:500 000. Czech Geological Survey, Prague

Cepedal A, Martin-Izard A, Reguilón R, Rodríguez-Pevida L, Spiering E, Ginzález-Nistal S (2000) Origin and evolution of the calcic and magnesian skarns hosting the El Valle-Boinás copper-gold deposit, Asturias (Spain). J Geochem Explor 71: 119-151

Chen X, Seitmuratova E, Wang Z, Chen Z, Han S, Li Y, YANG Y, Ye B, ShI W (2014) SHRIMP U-Pb and Ar-Ar geochronology of major porphyry and skarn $\mathrm{Cu}$ deposits in the Balkhash Metallogenic Belt, Central Asia, and geological implications. J Asian Earth Sci (part B) 79: 723-740

Chlupáč I, VRÁna S (1994) Regional geological subdivision of the Bohemian Massif on the territory of the Czech Republic (Report of the Working Group for Regional Geological Classification of the Bohemian Massif at the former Czechoslovak Stratigraphic Commission). J Czech Geol Soc 39: 127-144

Crowley QG, Floyd PA, Winchester JA, Franke W, HolLAND JG (2000) Early Palaeozoic rift-related magmatism in Variscan Europe: fragmentation of the Armorican Terrane Assemblage. Terra Nova 12: 171-180

Deer WA, Howie RA, Zussman J (1997) Rock-Forming Minerals. Volume 2A, Single-Chain Silicates. Geological Society of London, $2^{\text {nd }}$ ed., pp 1-668

Deer WA, Howie RA, Zussman J (2001) Rock-Forming Minerals. Volume 4A, Framework Silicates: Feldspars. Geological Society of London, $2^{\text {nd }}$ ed., pp 1-972

Dempíroví L (2010) The evaluation of precision and relative error of the main components of silicate analyses in Central Laboratory of the CGS. Zpr geol Výzk v Roce 2009: 326-330 (in Czech) 
DöRr W, Zulauf G (2010) Elevator tectonics and orogenic collapse of a Tibetan-style plateau in the European Variscides: the role of the Bohemian shear zone (Czech Republic). Int J Earth Sci 99: 299-325

Drahota P, Pertold Z, Pudilová M (2005) Three types of skarn in the northern part of the Moldanubian Zone, Bohemian Massif-implications for their origin. J Czech Geol Soc 50: 19-33

DROOP GTR (1987) A general equation for estimating $\mathrm{Fe}^{3+}$ concentrations in ferromagnesian silicates and oxides from microprobe analyses, using stoichiometric criteria. Min Mag 51: 431-435

Drost K, Gerdes A, Jeffries T, Linnemann U, Storey C (2011) Provenance of Neoproterozoic and early Paleozoic siliciclastic rocks of the Teplá-Barrandian Unit (Bohemian Massif): evidence from U-Pb detrital zircon ages. Gondwana Res 19: 213-231

EinAudi MT, Meinert LD, NewberRy RJ (1981) Skarn deposits. Econ Geol 77: 317-391

FARYAD SW (2009) The Kutná Hora Complex (Moldanubian Zone, Bohemian Massif): a composite of crustal and mantle rocks subducted to HP/UHP conditions. Lithos 109: $193-208$

Franke W (2000) The mid-European segment of the Variscides: tectonostratigraphic units, terrane boundaries and plate tectonic evolution. In: Franke W, HAAK W, ONCKEN O, TANner D (eds) Orogenic Processes: Quantification and Modelling in the Variscan Belt. Geological Society of London Special Publications 179: 35-63

Friedl G, Finger F, Paquette J-L, von Quadt A, McNaughton NJ (2004) Pre-Variscan geological events in the Austrian part of the Bohemian Massif deduced from U-Pb zircon ages. Int J Earth Sci (Geol Rundsch) 93: 802-823

Gaspar M, Knaack C, Meinert LD, Moretti (2008) REE in skarn systems: a LA-ICP-MS study of garnets from the Crown Jewel gold deposit. Geochim Cosmochim Acta 72: 185-205

Green TH, Ringwood AE (1968) Genesis of the calcalkaline igneous rock suite. Contrib Mineral Petrol 18: 105-162

HAJNÁ J, KACHLíK V, ŽÁK J (2011) Structure and stratigraphy of the Teplá-Barrandian Neoproterozoic, Bohemian Massif: a new plate-tectonic reinterpretation. Gondwana Res 19: 495-508

HanŽL P, HrdličKová K, Bešta J, BlažKová Š, BŘízová E, Dosbaba M, Fürych V, Kirchner K, Kryštofová E, LySenko V, Pertoldová J, RoštínskÝ P, RÝda K, Skácelová Z, Skácelová D, Tajčmanová L, Vít J, Zavř́lová A, Ž́́čKovÁ E (2008) Basic geological map ČR 1:25000 with explanations, 24-113 Nové Město na Moravě. Czech Geological Survey, Prague, pp 1-62 (in Czech)

Harley SL, Kelly NM, Möller A (2007) Zircon tiny but timely: zircon behaviour and the thermal histories of mountain chains. Elements 3: 25-30
HrdličKová K, BŘizová E, Fürych V, HanžL P, Kadlecová R, Kirchner K, Lysenko V, Lhotský P, Mrnková J, Pertoldová J, Roštínský P, Skácelová D, Skácelová Z, Vít J (2008) Basic geological map ČR $1: 25000$ with explanations, 23-224, Žd'ár nad Sázavou. Czech Geological Survey, Prague, pp 1-60 (in Czech)

Jamtveit B, Wogelius RA, Fraser DG (1993) Zonation patterns of skarn garnets, records of hydrothermal system evolution. Geology 21: 113-116

JANOUŠEK V, FARROW CM, ERBAN V (2006a) Interpretation of whole-rock geochemical data in igneous geochemistry: introducing Geochemical Data Toolkit (GCDkit). J Petrol 47: 1255-1259

Janoušek V, Gerdes A, VRÁna S, Finger F, Erban V, Friedl G, BRAITHWAITE CJR (2006b) Low-pressure granulites of the Lišov Massif, Southern Bohemia: Viséan metamorphism of Late Devonian plutonic arc rocks. J Petrol 47: 705-744

JAWECKI CH (1996) Fluid regime in the Austrian Moldanubian Zone as indicated by fluid inclusions. Mineral Petrol 58: $235-252$

KаснLíK V (1999) Relationship between Moldanubicum, the Kutná Hora Crystalline Unit and Bohemicum (Central Bohemia, Czech Republic): a result of polyphase Variscan nappe tectonics. J Czech Geol Soc 44: 201-291

KoŠLer J, Sylvester P (2003) Present trends and the future of zircon in geochronology: laser ablation ICPMS. Hanchar JM, Hoskin PWO (eds) Zircon. Mineralogical Society of America and Geochemical Society Reviews in Mineralogy and Geochemistry 53: 243-275

Košler J, Fonneland H, Sylvester P, Tubrett M, Pedersen $\mathrm{RB}$ (2002) U-Pb dating of detrital zircons for sediment provenance studies - a comparison of laser ablation ICPMS and SIMS techniques. Chem Geol 182: 605-618

Košler J, Konopásek J, Sláma J, VRána S (2014) U-Pb zircon provenance of Moldanubian metasediments in the Bohemian Massif. J Geol Soc, London 171: 83-95

KоткоvÁ J (1991) Skarns of the central part of the Krušné hory Mts. Věst Ústř Úst Geol 66: 215-232

Kouteк J (1950) Deposit of skarn-type at Vlastějovice in the area around the Sázava River. Rozpr Čs Akad Věd, ř mat prír Věd 60: 1-30 (in Czech)

KRETZ R (1983) Symbols for rock-forming minerals. Amer Miner 68: 277-279

Levresse G, González-Partida E, Carrillo-Chavez A, Tritlla J, Camprubí A, Cheilletz A, Gasquet D, DeLOULE E (2004) Petrology, U/Pb dating and (CO) stable isotope constraints on the source and evolution of the adakite-related Mezcala Fe-Au skarn district, Guerrero, Mexico. Miner Depos 39: 301-312

Li JW, Deng XD, Zhou MF, Liu YS, Zhao XF, Guo JL (2010) Laser ablation ICP-MS titanite U-Th-Pb dating of hydrothermal ore deposits: a case study of the Tonglushan $\mathrm{Cu}-\mathrm{Fe}-\mathrm{Au}$ skarn deposit, SE Hubei Province, China. Chem Geol 270: 56-67 
Linnemann U, Pereira F, Jefrries TE, Drost K, Gerdes A (2008) The Cadomian Orogeny and the opening of the Rheic Ocean: the diacrony of geotectonic processes constrained by LA-ICP-MS U-Pb zircon dating (OssaMorena and Saxo-Thuringian zones, Iberian and Bohemian massifs). Tectonophysics 461: 21-43

Litochleb J, Novák J, Šrein V (1997) Chemical composition of silicates from garnet-magnetite skarn from Horní Ves near Mariánské Lázně (Marienbad). Bull mineralpetrolog Odd Nár Muz (Praha) 4-5: 153-154 (in Czech)

LuDWIG KR (2003) Isoplot/Ex version 3.00. A geochronological toolkit for Microsoft Excel, User's Manual. Berkeley Geochronology Center Special Publications 4, pp 1-70

MeINERT LD (1998) A review of skarns that contain gold. In: LENTz DR (ed) Mineralized Porphyry/Skarn Systems. Mineralogical Association of Canada, Short Course Series 26: 359-414

Meinert LD, Hedenquist JW, Satoh H, Matsuhisa Y (2003) Formation of anhydrous and hydrous skarn in $\mathrm{Cu}-\mathrm{Au}$ ore deposits by magmatic fluids. Econ Geol 98: 147-156

Meinert LD, Dipple GM, Nicolescu S (2005) World Skarn Deposits. In: Hedenquist JW, Thompson JFH, GoldFarb RJ, Richards JP (eds) Economic Geology $100^{\text {th }}$ Anniversary Volume: 299-336

Nahodilová R, Faryad SW, Dolejš D, Tropper P, Konzett $\mathrm{J}$ (2011) High-pressure partial melting and melt loss in felsic granulites in the Kutná Hora Complex, Bohemian Massif (Czech Republic). Lithos 125: 641-658

Nahodilová R, ŠTíPskÁ P, Powell R, KoŠler J, RaceK M (2014) High-Ti muscovite as a prograde relict in high pressure granulites with metamorphic Devonian zircon ages (Běstvina granulite body, Bohemian Massif): consequences for the relamination model of subducted crust. Gondwana Res 25: 630-648

NĚMEC D (1991) Regional typization of the iron skarns of the Bohemian-Moravian Heights (Českomoravská vrchovina). Acta Mus Moraviae, Sci Nat 76: 51-82

Nicolescu S, Cornell DH, Sodervall U, Odelius H (1998) Secondary ion mass spectrometry analysis of rare earth elements in grandite garnet and other skarn related silicates. Eur J Mineral 10: 251-259

O'BRIEN P J, RÖTZLER J (2003) High-pressure granulites: formation, recovery of peak conditions and implications for tectonics. J Metamorph Geol 21: 3-20

Perraki M, Faryad SW (2014) First finding of microdiamond, coesite and other UHP phases in felsic granulites in the Moldanubian Zone: implications for deep subduction and a revised geodynamic model for Variscan Orogeny in the Bohemian Massif. Lithos 202-203: 157-166

Pertold Z, Pertoldová J, PotužÁk M, Pudilová M, Bendl J, Janoušek V, Zachariáš J, Spiro B, Greenwood PB (1997) Skarns of the Bohemian massif: origin in closed or open systems? J Czech Geol Soc 42: 69
Pertold Z, Pertoldová J, Pudilová M (2000) Metamorphic history of skarns in the Gföhl Unit, Moldanubicum, Bohemian Massif, and implication for their origin. Acta Univ Carol, Geol 41: 157-166

Pertoldová J, Pertold Z, Pudilová M (1998) Metamorphic development of skarns at Pernštejn, Svratka Crystalline Complex, Bohemian Massif. J Czech Geol Soc 43: 191-202

Pertoldová J, Týcová P, Verner K, Košuličová M, Pertold Z, KoŠler J, Konopásek J, Pudilová M (2009) Tectonometamorphic history of skarns, origin and age of their protolith and implications for genetic interpretation; an example from the Svratka Unit, the Moldanubian Zone, and the Kutná Hora Unit, Bohemian Massif. J Geosci 54: 101-134

Pertoldová J, Verner K, Vrána S, Buriánek D, Štědrá V, Vondrovic L (2010) Comparison of lithology and tectonometamorphic evolution of units at northern margin of the Moldanubian Zone: implications for geodynamic evolution in the northeastern part of the Bohemian Massif. J Geosci 55: 299-319

Pitra P, Guiraud M (1996) Probable anticlockwise P-T evolution in extending crust: Hlinsko region, Bohemian Massif. J Metamorph Geol 14: 49-60

PotuŽÁk M (1996) Skarn in Vlastějovice at Holý vrch. Unpublished MSc. thesis, Charles University, Prague, pp 1-138 (in Czech)

Pouchou JL, Pichoir F (1985) "PAP” $(\phi-\rho-Z)$ procedure for improved quantitative microanalysis. In: Armstrong JT (ed) Microbeam Analysis. San Francisco Press, pp 104-106

POVONDRA P, VRÁNA S (1996) Tourmaline and associated minerals in alkali-feldspar orthogneiss near Hluboká nad Vltavou. J Czech Geol Soc 41: 191-200

Racek M, Ští́pská P, Pitra P, Schulmann K, Lexa O (2006) Metamorphic record of burial and exhumation of orogenic lower and middle crust: a new tectonothermal model for the Drosendorf Window (Bohemian Massif, Austria). Mineral Petrol 86: 221-251

Racek M, Štípská P, Powell R (2008), Garnet-clinopyroxene intermediate granulites in the St. Leonhard Massif of the Bohemian Massif: ultrahigh-temperature metamorphism at high pressure or not? J Metamorph Geol 26: 253-271

Rejchrt M, Břízová E, Fürych V, Hanžl P, Hradecká L, HrdičKová K, Kadlecová R, Kirchner K, Lysenko V, Mlčoch B, Nahodilová R, Novák M, Otava J, PerTOldová J, Rambousek P, RoŠTínskÝ P, RudolskÝ J, SkÁcelová D, SkÁcelová Z, TÝcová P, Vít J, ŽÁčKovÁ E (2009) Basic geological map ČR $1: 25000$ with explanations, 23-222 Krucemburk. Czech Geological Survey, Prague (in Czech)

RichARD LR (1995) MinPet: Mineralogical and Petrological Data Processing System, version 2.02. MinPet Geological Software, Québec, Canada 
Richard LR, Clarke DB (1990) AMPHIBOLE: a program for calculating structural formulae and for classifying and plotting analyses of amphiboles. Amer Miner 75: 421-423

Robinson P, Spear FS, Schumacher JC, Laird J, Klein C, Evans BW, Doolan BL (1981) Phase relations of metamorphic amphiboles: natural occurrence and theory. In: Veblen DR, RibBe PH (eds) Amphiboles: Petrology and Experimental Phase Relations. Mineralogical Society of America Reviews in Mineralogy 9B: 1-228

ROBERTS MP, Finger F (1997) Do U-Pb zircon ages from granulites reflect peak metamorphic conditions? Geology 25: 319-322

Schulmann K, Kröner A, Hegner E, Wendt I, Konopásek J, LEXA O, ŠTíPSKÁ P (2005) Chronological constraints on the pre-orogenic history, burial and exhumation of deep-seated rocks along the eastern margin of the Variscan Orogen, Bohemian Massif, Czech Republic. Amer J Sci 305: 407-448

Schulmann K, Konopásek J, Janoušek V, Lexa O, Lardeaux JM, Edel JB, ŠTíPSKÁ P, UlRich S (2009) An Andean type Palaeozoic convergence in the Bohemian Massif. C R Geosci 341: 266-286

Shen JF, Santosh M, Li SR, Zhang HF, Yin N, Dong GC, Wang YJ, Ma GG, Yu HJ (2013) The Beiminghe skarn iron deposit, eastern China: geochronology, isotope geochemistry and implications for the destruction of the North China Craton. Lithos 156-159: 218-229

Sláma J, Košler J, Condon DJ, Crowley JL, Gerdes A, Hanchar JM, Horstwood MSA, Morris GA, Nasdala L, Norberg N, Schaltegger U, Schoene B, Tubrett MN, Whitehouse MJ (2008) Plešovice zircon - a new natural reference material for $\mathrm{U}-\mathrm{Pb}$ and $\mathrm{Hf}$ isotopic microanalysis. Chem Geol 249: 1-35

Synek J, Oliveriová D (1993) Terrane character of the north-east margin of the Moldanubian Zone: the Kutná Hora Crystalline Complex, Bohemian Massif. Geol Rundsch 82: 566-582

Šrein V, ŠreinovÁ B (2000) Mineralogy of the skarns of the Bohemian part of the western and central Krušné hory mountains. Acta Montana - series A17: 67-108

ŠTĚDRÁ V, NAHODILOVÁ R (2009) High-pressure metabasic rocks from the Kutná Hora Complex: geological position and petrology of exotic lithologies along the segmented Moldanubian margin, Bohemian Massif. J Geosci 54: $135-157$

ŠTĚdRÁ V, ČÁp P, ČECh S, Dosbaba M, Dušek K, Dvořák I, Holásek O, Hradecká L, Hroch T, Kadlecová R, Klečá́ J, Kratochvílová H, Krejčí Z, Mašek D, Ondovčin T, Rejchrt M, Skácelová D, Skácelová Z, ŠVÁBENICKÁ L, VodRÁžKA R (2011) Basic geological map ČR 1:25000 with explanations, 13-324 Kutná Hora. Czech Geological Survey, Prague (in Czech)

TajČmanová L, Konopásek J, Schulmann K (2006) Thermal evolution of the orogenic lower crust during exhumation within a thickened Moldanubian root of the Variscan belt of Central Europe. J Metamorph Geol 24: 119-134

Tajčmanová L, Soejono I, Konopásek J, KoŠLer J, KLÖTZl U (2010) Structural position of high-pressure felsic to intermediate granulites from NE Moldanubian domain (Bohemian Massif). J Geol Soc, London 167: 329-345

Teipel U, EichHorn R, Loth G, Rohrmüller J, Höll R, KenNedy A (2004) U-Pb SHRIMP and Nd isotopic data from the western Bohemian Massif (Bayerischer Wald, Germany): implications for Upper Vendian and Lower Ordovician magmatism. Int J Earth Sci 93: 782-801

Tropper P, Konzett J, Finger F (2005). Experimental constraints on the formation of high-P/high T granulites in the Southern Bohemian Massif. Eur J Mineral 17: 343-356

Urban M, Synek J (1995) Moldanubian Zone - Structure. In: Dallmeyer RD, Franke W, Weber K (eds) Pre-Permian Geology of Central and Eastern Europe. Springer, Berlin, pp 429-443

Verner K, Buriánek D, Vrána S, Vondrovic L, Pertoldová J, HanžL P, Nahodilová R (2009) Lithological and structural features of geological units along the northern periphery of the Moldanubian Zone: a review of the geology of the northeastern Variscides. J Geosci 54: 87-100

ViLLA IM (2010) Disequilibrium textures versus equilibrium modelling: geochronology at the crossroads. SpALLA MI, Marotta AM, Gosso G (eds) Advances in Interpretation of Geological Processes: Refinement of Multi-scale Data and Integration in Numerical Modelling. Geological Society of London Special Publications 332: 1-15

VRÁNA S (1987) Garnet-fassaitic pyroxene skarn from the granulite complex of southern Bohemia. Věst Ústř Úst Geol 62: 193-206

VRÁNA S, KRÖNER A (1995) Pb-Pb zircon ages for tourmaline alkali-feldspar orthogneiss from Hluboká nad Vltavou in southern Bohemia. J Czech Geol Soc 40:127-135

Vrána S, Blümel P, Petrakakis K (1995) Moldanubian Zone - Metamorphic Evolution. In: Dallmeyer RD, Franke W, Weber K (eds) Pre-Permian Geology of Central and Eastern Europe. Springer, Berlin, pp 453-466

VRÁNA S, ŠTĚDRÁ V, FišERA M (2005) Petrology and geochemistry of the Běstvina granulite body metamorphosed at eclogite facies conditions, Bohemian Massif. J Czech Geol Soc 50: 95-106

VRÁNA S, ŠTĚDRÁ V, NAHOdilová R (2009) Geochemistry and petrology of high-pressure albite-K-feldspar-kyanite-garnet felsic gneisses and granulites from the Kutná Hora Unit. J Geosci 54: 159-179

Wiedenbeck M, Allé M, Corfu F, Griffin WL, Meier M, Oberli F, von Quadt A, Roddick JC, Spiegel W (1995) Three natural zircon standards for $\mathrm{U}-\mathrm{Th}-\mathrm{Pb}$, Lu-Hf, trace element and REE analyses. Geostand Newsl 19: 1-23

Xie G, Mao J, Zhao H, Wei K, Jin S, Pan H, Ke Y (2011) Timing of skarn deposit formation of the Tonglushan ore 
district, southeastern Hubei Province, Middle-Lower Yangtze River Valley metallogenic belt and its implications. Ore Geol Rev 43: 62-77

ZoubeK V (1946) Notes to the geology of the crystalline complexes of the Bohemian Massif. Sbor Stát Geol Úst 25: 339-398

Ž́ÁČEK V (1997) Compositional evolution of garnet in the regionally metamorphosed Moldanubian skarn, Vlastějovice, Bohemia - evidence of the preservation of early stages pre-dating regional metamorphism. Věst Čes Geol Úst 72: 37-48

ŽÁČEK V (2007) Potassian hastingsite and potassic hastingsite from garnet-hedenbergite skarn at Vlastějovice, Czech Republic. Neu Jb Mineral, Abh 184: 161-168
Žáček V, NovÁk M, Raimboult L, Zachariáš J, Ackerman L (2003) Locality No. 8, Vlastějovice near Ledeč nad Sázavou. In: NovÁk M (ed.) LERM 2003, International Symposium on Light Elements in Rock-forming Minerals, Field Trip Guidebook, Masaryk University Brno, pp 61-70 Žák J, Verner K, Janoušek V, Holub F V, Kachlík V, Finger F, Hajná J, Tomek F, Vondrovic L, Trubač J (2014) A plate-kinematic model for assembly of the Bohemian Massif constrained by structural relationships around granitoid plutons. In: Schulmann K, Martínez Catalán JR, Lardeaux JM, Janoušek V, OGgiano G (eds) The Variscan Orogeny: Extent, Timescale and the Formation of the European Crust. Geological Society London Special Publications 405: pp 169-196 